\title{
Ichnodiversity and bathymetric range of microbioerosion traces in polar barnacles of Svalbard
}

\author{
Neele Meyer, ${ }^{1,2}$ (1) Max Wisshak ${ }^{2}$ (1) \& André Freiwald ${ }^{1,2}$ (1) \\ ${ }^{1}$ Faculty of Geosciences, University of Bremen, Bremen, Germany \\ ${ }^{2}$ Senckenberg am Meer, Marine Research Department, Wilhelmshaven, Germany
}

\section{Abstract}

This first comprehensive investigation of microbioerosion traces in polar barnacles addresses two bathymetrical transects from the intertidal down to subtidal water depths in two different carbonate factories in the Svalbard Archipelago: the bay Mosselbukta and the ocean bank Bjørnøy-Banken. Scanning electron microscopy of epoxy resin casts of barnacle shells yielded 20 different microendolithic bioerosion traces, probably produced by cyanobacteria (three), chlorophytes (two), rhodophytes (one), sponges (one), foraminifera (three), fungi (nine) and bacteria (one). The lowest ichnodiversity in both locations was observed in the shallow euphotic zone and is likely a result of strong temperature fluctuations, extreme seasonality of light levels and episodic sea-ice cover. At 25-150 m water depth, the ichnodiversity remains relatively constant (9-13 ichnospecies), albeit with differing ichnospecies composition, generally dominated by borings from chlorophytes and fungi. Ichnotaxa at Mosselbukta and Bjørnøy-Banken were similar in numbers but differed in abundance and slightly also in ichnospecies composition. Statistical tests indicate that water depth (affecting the availability of light) is the most significant driver for the development of different microbioerosion trace assemblages across the bathymetrical transects. In contrast, no significant differences in ichnodisparity were found, indicating a comparable suite of architectural designs of the microborings throughout bathymetry and location. The comparison of our results with literature data confirms a decrease in ichnodiversity from lower to higher latitudes, although targeted bioerosion analyses from other polar environments are needed to gain a more complete picture of the role of bioerosion in polar carbonate factories.
\end{abstract}

\section{Keywords}

Bioerosion; ichnotaxonomy; ichnodisparity; Arctic; Mosselbukta; Bjørnøy-Banken

\section{Correspondence}

Neele Meyer, Senckenberg am Meer, Marine Research Department, Südstrand 40, DE-26382 Wilhelmshaven, Germany. E-mail: neele.meyer@senckenberg.de

\section{Abbreviations \\ ANOSIM: analysis of similarities NMDS: non-metric multidimensional scaling PAR: photosynthetically active radiation SIMPROF: similarity profile analysis SEM: scanning electron microscopy}

\section{Introduction}

Bioerosion is the degradation of hard substrates by biological means (Neumann 1966) and plays an important ecological and biosedimentological role from low to high latitudes. The process is divided into internal and external bioerosion (Bromley 2004). Internal bioeroders excavate the substrate for shelter, whilst external ones bioerode by means of grazing or fixation (Bromley 2004; Tribollet et al. 2011). Internal bioerosion is further subdivided into micro- (e.g., by cyanobacteria, chlorophytes, fungi) and macrobioerosion (e.g., by polychaetes, bivalves, sponges), distinguished by the trace dimensions (smaller or larger than $1 \mathrm{~mm}$ ) they leave behind in the substrate (Wisshak 2012). These bioerosion traces and trace fossils are taxonomically treated as ichnotaxa. They are commonly analysed via SEM of epoxy casts, prepared by applying the vacuum cast-embedding technique (Wisshak 2006, 2012).
Although bioerosion is a key process on a global scale, bioerosion research has so far mainly focussed on subtropical and tropical environments, there particularly on coral reefs, and therefore considering primarily the photic zone. High latitudes have received much less attention (for a review, see Wisshak 2006), and the North Atlantic is represented, inter alia, by studies off the Scottish coast (Akpan \& Farrow 1985; Glaub et al. 2002), Norway (Bromley \& Hanken 1981; Schmidt \& Freiwald 1993; Glaub et al. 2002) and Sweden (Wisshak et al. 2005). Spitsbergen was, for instance, studied with a focus on polychaete bioerosion (Hanken et al. 2012) and the Canadian Arctic with a focus on macroborings (Aitken \& Risk 1988). A comprehensive investigation of bioerosion traces, considering a broader bathymetrical range and including the different types of bioerosion traces, is lacking for polar environments and would help to better understand the role of bioerosion in polar carbonate factories. 
Therefore, this study establishes a comprehensive catalogue of microbioerosion traces in two high-latitude carbonate depositional environments in the Svalbard Archipelago at $74^{\circ}$ and $80^{\circ}$ northern latitude. Barnacles were the chosen substrate because they are sessile calcifiers that are most likely to bear bioerosion traces from the corresponding water depth when sampled alive. They occur from the intertidal down to aphotic water depths in Svalbard, allowing an establishment of bathymetric transects extending from the shore to $125 \mathrm{~m}$ water depth at Mosselbukta (northern Spitsbergen) and east of the island of Bjørnøya (southernmost Svalbard). We provide a statistical ichnodiversity analysis to compare these two locations. This approach allows us to evaluate the ichnodiversity variability of bioerosion within the Arctic environment and at different water depths. In addition, we apply the ichnodisparity concept to determine the diversity of architectural designs in bioerosion traces and, therefore, the established behavioural patterns of microbioeroders (Buatois et al. 2017). Finally, we assess our observations in the context of a low to high latitudinal gradient.

\section{Methods}

\section{Study sites}

Svalbard (Fig. la) is in an Arctic environment on the north-western margin of the Barents Shelf, approximately
$650 \mathrm{~km}$ north of the Norwegian mainland. In 2016, Mosselbukta, our first study site, near the northern tip of Spitsbergen (Fig. 1b), was covered by drift ice for 14 days, whereas Bjørnøy-Banken, the second study site in the south (Fig. 1c), was covered by very open to open drift ice at the end of March for about a week (Fig. 2; Norwegian Meteorological Institute 2019).

Mosselbukta is influenced by 123 days of polar night (data for 2016 obtained from NOAA Global Monitoring Laboratory [2020]; Fig. 2). The local carbonate factory is characterized by rhodoliths beds, which cover up to $100 \%$ of the seafloor in some areas (Teichert et al. 2014). Bjørnøy-Banken is a shallow $(20-150 \mathrm{~m})$ shelf platform to the east of Bjørnøya (Bear Island), where extensive biogenic carbonate sediments accumulate in a strong hydrodynamic regime (Henrich et al. 1997; Wisshak et al. 2017; Wisshak et al. 2019), and experiences 88 days of polar night (data for 2016 obtained from NOAA Global Monitoring Laboratory [2020]). The temperature in 2006 in Mosselbukta at $46 \mathrm{~m}$ water depth ranged from $-2{ }^{\circ} \mathrm{C}$ to $6.3{ }^{\circ} \mathrm{C}$, whereas salinity remained relatively constant from 33.2 to 35.4 (Wisshak et al. 2019). The boundary between the euphotic and dysphotic zones in summer was between 20 and $25 \mathrm{~m}$ water depth at Mosselbukta, whilst the base of the dysphotic zone was located at ca. $64 \mathrm{~m}$ (Teichert et al. 2014). Neither annual temperature or salinity data nor PAR-measurements for the determination of photic

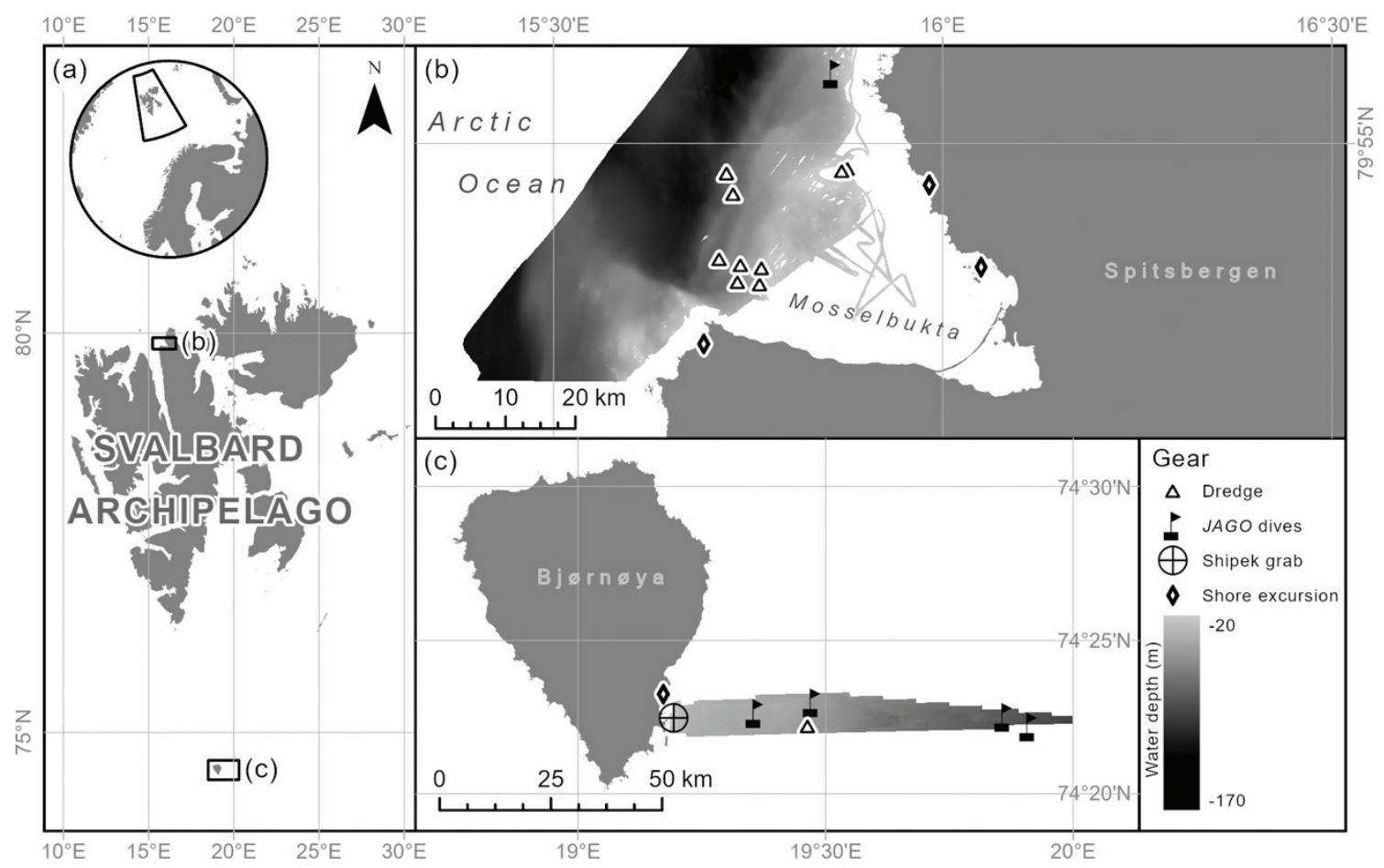

Fig. 1 Map of the (a) Svalbard Archipelago and bathymetry for (b) Mosselbukta and (c) Bjørnøy-Banken (east of Bjørnøya), including stations for sample collection and applied gear of recovery (station metadata are listed in Table 1). 


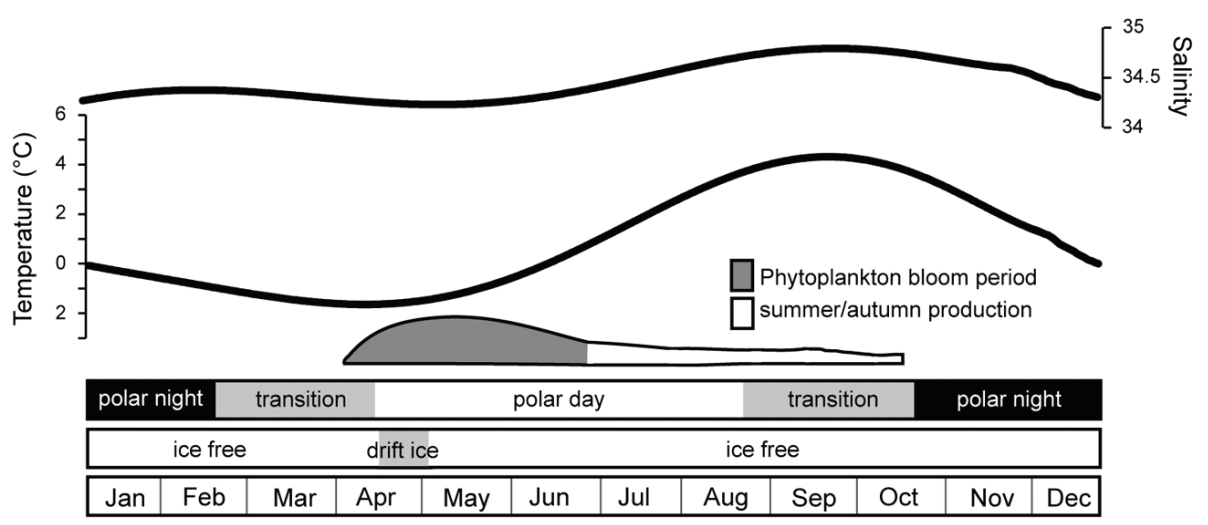

Fig. 2 Schematic overview of the seasonality at Mosselbukta. (Salinity and temperature data for 2006 simplified after Wisshak et al. [2019]. Phytoplankton bloom and subsequent summer/autumn production based on Zenkevitch [1963]. Polar night and day data retrieved from the NOAA Global Monitoring Laboratory [2020]. Ice data for 2016 obtained via the ice chart archive of the Norwegian Meteorological Institute [2019].)

zones are available for Bjørnøy-Banken. However, PAR measurements via lander deployments at Mosselbukta and Bjørnøy-Banken in the summer of 2016 showed higher (tidal) current-induced turbidity and lower light levels at Bjørnøy-Banken (Wisshak et al. 2019), suggesting that the photic zonation is a bit more condensed compared with Mosselbukta. A detailed environmental characterization for the two study sites is provided by Wisshak et al. (2019).

\section{Sample collection}

During the MSM55 cruise with the RV Maria S. Merian in the summer of 2016 (Wisshak et al. 2017), we collected live balanids (barnacles) of the species Balanus balanus (Linnaeus, 1758) with a rock dredge, a Shipek grab and the research submersible $J A G O$ along bathymetrical transects, growing on boulders or Chlamys islandica (Müller, 1776). The collection was complemented by a few Balanus crenatus Bruguière, 1789 sampled in the intertidal zone during shore excursions. Both species live in association down to $60 \mathrm{~m}$ water depth, although $B$. crenatus is primarily a sublittoral species, whereas $B$. balanus prefers deeper waters (e.g., Barnes \& Powell 1953; Barnes \& Barnes 1954; Luther 1987). In accordance with the approach by Barnes \& Barnes (1954), our analysed specimens of B. balanus were perennial and at least four to six years old, as some of the detached balanids had a rostro-carinal diameter of 30-40 mm (consistent with observations of Balanus balanoides in Spitsbergen by Feyling-Hanssen [1953] and Luther [1987]). Balanus crenatus specimens were likely younger, as they were analysed to have a lifespan of one to two years (Barnes \& Powell 1953).

Balanids are suitable substrates for bioerosion studies (e.g., Glaub et al. 2002; Feussner et al. 2004) and are abundant in polar waters around Svalbard at all water depths (Fig. 3). Balanids were collected in roughly $25 \mathrm{~m}$ depth intervals, spanning the intertidal to 95 and $125 \mathrm{~m}$ water depth at Bjørnøy-Banken and Mosselbukta, respectively (Table 1, Fig. 1b, c).

\section{Sample preparation and analysis}

Immediately after the recovery, balanids were soaked in freshwater to remove the salt and then dried at $50{ }^{\circ} \mathrm{C}$. Prior to the vacuum cast-embedding technique (Wisshak 2006, 2012), organic material was removed with sodium hypochlorite (customary cleaning agent); afterwards, the specimens were rinsed with deionized water and dried at $30{ }^{\circ} \mathrm{C}$ for $12 \mathrm{hrs}$. To enhance the impregnation with R\&G "water clear" epoxy resin, the balanids were placed in a CitoVac (Struers) vacuum chamber. Once the resin cured, the embedded samples were cut with a rock saw and treated with ca. 5\% hydrochloric acid to remove the carbonate. One hundred seventeen casts were glued onto stubs and sputter-coated with gold (Cressington sputter coater 108) for SEM investigation using a Tescan VEGA3 xmu scanning electron microscope, using the secondary electron detector at $20 \mathrm{kV}$.

Bioerosion traces were identified at ichnospecies level where applicable and otherwise treated in open nomenclature or addressed by informal names. A semi-quantitative analysis of the identified bioerosion traces was performed because actual quantification is unfeasible for bioerosion traces. There is a wide range of sizes, traces may superimpose each other, and whilst individual borings can be easily recognized in some of the ichnotaxa, this is impossible for larger and intergrown networks. We classified each ichnotaxon per sample into one of four abundance classes: absent (0); very rare, only one or very few specimens (1); rare, few specimens (2); common, many specimens but not dominant (3); very common or dominant (4). These were then averaged by the number of investigated samples per water depth (after Wisshak et al. 2011). 

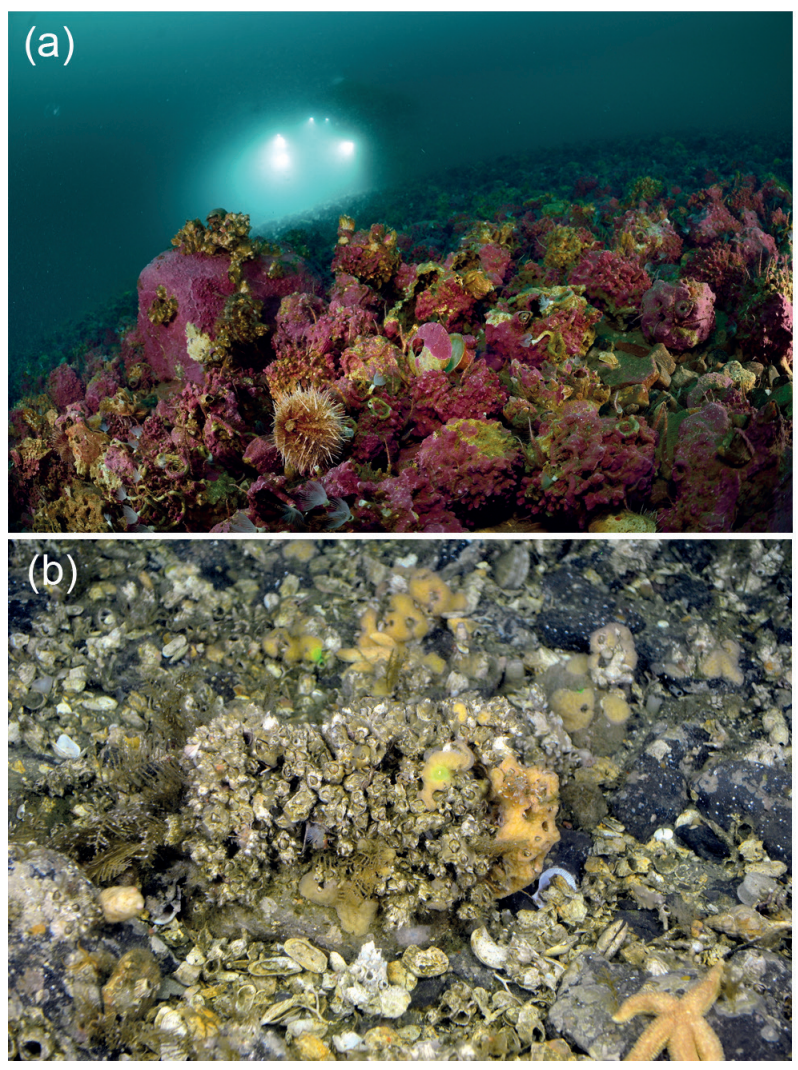

Fig. 3 The seafloor in Svalbard carbonate factories, illustrating the abundance of balanids at (a) the rhodolith beds in Mosselbukta (ca. $45 \mathrm{~m}$ water depth; submersible JAGO in the background; photo courtesy of Solvin Zankl) and at (b) the carbonate platform at Bjørnøy-Banken (ca. 100 m water depth).

\section{Statistical ichnodiversity analyses}

To evaluate the ichnodiversity, we used the $\mathrm{R}$ version 3.5.2 software (R Core Team 2018) to perform multivariate normality tests (Mardia and Royston) using the mvn package (Korkmaz et al. 2014). Prior to the following tests, we computed a Bray-Curtis dissimilarity matrix using the vegan $R$ package (Oksanen et al. 2018) from the untransformed ordinal data, which is a common practice for an ANOSIM (Hammer \& Harper 2008; Greenacre \& Primicerio 2013) and can be used for relative abundance data (Greenacre \& Primicerio 2013). For the non-parametric ANOSIM test, we used vegan $(999$ permutations) to statisically test that there was no significant difference between two or more groups (null hypothesis). The output is the $p$ value and an $R$ value between -1 and 1 ; a number close to 0 means that there is no difference between sites. The vegan package was also utilized for the NMDS plots to visualize similarities in two dimensions (Hammer \& Harper 2008). The clustsig package (Whitaker \& Christman 2014) with the cluster method "average" was used for the cluster analyses with SIMPROF to determine and visualize the number of significant clusters. The biodiversity indices Margalef's richness index $d$, Simpson index of dominance $\lambda$ and diversity $1-\lambda$, Shannon index $H^{\prime}\left(\log _{e}\right)$ and Pielou's evenness $J^{\prime}$ were calculated using PRIMER 6, version 6.1.16, software (Plymouth Marine Laboratory). Whilst these indices are usually based on counts of specimens (Hammer \& Harper 2008), we used our ordinal data and transformed the abundance classes in different orders of magnitude (4 was transformed to $1000 ; 3$ to $100 ; 2$ to 10 ; 1 kept as 1) to obtain relative abundances, following the approach introduced by Wisshak et al. (2011).

\section{Results}

\section{Ichnodiversity of microborings}

A total of 20 different microbioerosion traces were detected: 18 ichnotaxa in 71 samples from Mosselbukta and 16 traces in 46 samples from Bjørnøy-Banken. Four traces were unique to Mosselbukta and two to Bjørnøy-Banken. All ichnotaxa are dwelling traces in the ethological class "domichnia" (after Vallon et al. 2016). Traces were grouped in accordance with the inferred or assumed type of microendolithic trace-makers (Table 2); these include cyanobacteria (three traces), chlorophytes (two), rhodophytes (one), sponges (one), foraminifera (three), fungi (nine) and bacteria (one).

Composition of ichnotaxa varied slightly between location and water depth and in abundance (Table 3). In the shallow euphotic zone, mainly microborings by cyanobacteria (Fascichnus ichnospecies), chlorophytes (e.g., Cavernula pediculata) and rhodophytes (Conchocelichnus seilacheri) were recorded. Traces of unknown organotrophic producers such as foraminifera or fungi (e.g., Pyrodendrina arctica or Flagrichnus ichnospecies) were rare. The deep euphotic to dysphotic zone was densely colonized and had the highest ichnodiversity, with Ichnoreticulina elegans as the dominant ichnotaxon, followed by Flagrichnus isp. and C. seilacheri. The aphotic zone was characterized by a high abundance of inferred or assumed fungal microborings (e.g., Saccomorpha guttulata) and a high ichnodiversity (Table 3).

\section{Description of some microborings}

In the following, we elaborate on the morphological characters of microborings whose morphology differs from the original diagnoses of the respective ichnotaxa. A few traces are described here in informal names, indicated by quotation marks. Abundance and quantification of all observed microborings are outlined in Table 3. 
Table 1 List of analysed samples, including water depth, station number, coordinates, gear and number of samples obtained during the MSM55 cruise. For the JAGO and the rock dredge, the coordinates indicate the location of the vessel at the start of the survey. Station locations are shown in Fig. 1.

\begin{tabular}{|c|c|c|c|c|c|}
\hline Depth (m) & Station & & & Gear & No. of samples \\
\hline \multicolumn{6}{|c|}{ Mosselbukta } \\
\hline 0 & MSM55 437-1 & $79^{\circ} 54.44^{\prime} \mathrm{N}$ & $15^{\circ} 58.95^{\prime} \mathrm{E}$ & Shore excursion & 4 \\
\hline 0 & MSM55 437-2 & $79^{\circ} 53.33^{\prime} \mathrm{N}$ & $16^{\circ} 02.95^{\prime} \mathrm{E}$ & Shore excursion & 5 \\
\hline 0 & MSM55 451-1 & $79^{\circ} 52.29^{\prime} \mathrm{N}$ & $15^{\circ} 41.57^{\prime} \mathrm{E}$ & Shore excursion & 7 \\
\hline $0-20$ & MSM55 447-1 & $79^{\circ} 55.94^{\prime} \mathrm{N}$ & $15^{\circ} 51.47^{\prime} \mathrm{E}$ & JAGO dives & 10 \\
\hline $0-20$ & MSM55 437-1 & $79^{\circ} 54.44^{\prime} \mathrm{N}$ & $15^{\circ} 58.95^{\prime} \mathrm{E}$ & Shore excursion & 9 \\
\hline 25 & MSM55 468-1 & $79^{\circ} 54.78^{\prime} \mathrm{N}$ & $15^{\circ} 52.65^{\prime} \mathrm{E}$ & Dredge & 4 \\
\hline 25 & MSM55 468-2 & $79^{\circ} 54.75^{\prime} \mathrm{N}$ & $15^{\circ} 52.21^{\prime} \mathrm{E}$ & Dredge & 4 \\
\hline 50 & MSM55 443-1 & $79^{\circ} 53.22^{\prime} \mathrm{N}$ & $15^{\circ} 45.88^{\prime} \mathrm{E}$ & Dredge & 4 \\
\hline 50 & MSM55 443-2 & $79^{\circ} 53.44^{\prime} \mathrm{N}$ & $15^{\circ} 46.02^{\prime} \mathrm{E}$ & Dredge & 4 \\
\hline 75 & MSM55 456-1 & $79^{\circ} 53.25^{\prime} \mathrm{N}$ & $15^{\circ} 44.17^{\prime} \mathrm{E}$ & Dredge & 4 \\
\hline 75 & MSM55 456-2 & $79^{\circ} 53.48^{\prime} \mathrm{N}$ & $15^{\circ} 44.40^{\prime} \mathrm{E}$ & Dredge & 4 \\
\hline 100 & MSM55 418-1 & $79^{\circ} 53.56^{\prime} \mathrm{N}$ & $15^{\circ} 42.76^{\prime} \mathrm{E}$ & Dredge & 4 \\
\hline 125 & MSM55 480-1 & $79^{\circ} 54.72^{\prime} \mathrm{N}$ & $15^{\circ} 43.33^{\prime} \mathrm{E}$ & Dredge & 4 \\
\hline 125 & MSM55 480-2 & $79^{\circ} 54.44^{\prime} \mathrm{N}$ & $15^{\circ} 43.83^{\prime} \mathrm{E}$ & Dredge & 4 \\
\hline \multicolumn{6}{|c|}{ Bjørnøy-Banken } \\
\hline $0-20$ & MSM55 507-2 & $74^{\circ} 23.25^{\prime} \mathrm{N}$ & $19^{\circ} 10.33^{\prime} \mathrm{E}$ & Shore excursion & 8 \\
\hline 21 & MSM55 501-1 & $74^{\circ} 22.48^{\prime} \mathrm{N}$ & $19^{\circ} 11.57^{\prime} \mathrm{E}$ & Shipek grab & 6 \\
\hline 38 & MSM55 489-1 & $74^{\circ} 22.62^{\prime} \mathrm{N}$ & $19^{\circ} 21.42^{\prime} \mathrm{E}$ & JAGO dives & 8 \\
\hline 50 & MSM55 484-1 & $74^{\circ} 22.98^{\prime} \mathrm{N}$ & $19^{\circ} 28.35^{\prime} \mathrm{E}$ & JAGO dives & 4 \\
\hline 50 & MSM55 488-3 & $74^{\circ} 22.50^{\prime} \mathrm{N}$ & $19^{\circ} 27.80^{\prime} \mathrm{E}$ & Dredge & 4 \\
\hline 76 & MSM55 516-1 & $74^{\circ} 22.50^{\prime} \mathrm{N}$ & $19^{\circ} 51.55^{\prime} \mathrm{E}$ & JAGO dives & 8 \\
\hline 95 & MSM55 522-1 & $74^{\circ} 22.19^{\prime} \mathrm{N}$ & $19^{\circ} 54.55^{\prime} \mathrm{E}$ & JAGO dives & 8 \\
\hline
\end{tabular}

Table 2 List of ichnotaxa recorded from Mosselbukta and Bjørnøy-Banken, the inferred or assumed (in parentheses) microendoliths based on the original interpretation of the ichnotaxon authority and the relevant figure number.

\begin{tabular}{|c|c|c|c|c|}
\hline Microendolith & Ichnotaxa & Mosselbukta & Bjørnøy-Banken & Fig. \\
\hline (Cyanobacteria) & "Fascichnus isp. I" & $x$ & & $4 a$ \\
\hline (Cyanobacteria) & "Fascichnus isp. II" & & $x$ & $4 b$ \\
\hline (Cyanobacteria) & Planobola cf. microgota Schmidt, 1992 & $x$ & $x$ & $4 c$ \\
\hline Chlorophytes & Cavernula pediculata Radtke, 1991 & $x$ & & $4 d$ \\
\hline Chlorophytes & Ichnoreticulina elegans (Radtke, 1991) & $x$ & $x$ & $4 e-g$ \\
\hline Rhodophytes & Conchocelichnus seilacheri Radtke et al., 2016 & $x$ & $x$ & $4 g-i$ \\
\hline (Sponges) & Entobia mikra Wisshak, 2008 & $x$ & $x$ & $4 j$ \\
\hline Foraminifera & Nododendrina europaea (Fischer, 1875) & $x$ & $x$ & $4 k, 1$ \\
\hline (Foraminifera) & Pyrodendrina arctica Wisshak, 2017 & $x$ & $x$ & $6 e, f$ \\
\hline (Foraminifera) & Pyrodendrina villosa Wisshak, 2017 & $x$ & $x$ & $6 \mathrm{~g}$ \\
\hline (Fungi) & Flagrichnus baiulus Wisshak \& Porter, 2006 & $x$ & $x$ & $5 a, b$ \\
\hline (Fungi) & Flagrichnus cf. baiulus Wisshak \& Porter, 2006 & $x$ & $x$ & $5 c, d$ \\
\hline (Fungi) & Flagrichnus cf. profundus Wisshak \& Porter, 2006 & $x$ & $x$ & $5 e, f$ \\
\hline (Fungi) & Orthogonum-form 1 sensu Wisshak et al., 2005 & & $x$ & $6 a$ \\
\hline (Fungi) & Orthogonum lineare Glaub, 1994 & $x$ & $x$ & $6 b$ \\
\hline (Fungi) & Orthogonum tubulare Radtke, 1991 & $x$ & $x$ & $6 c$ \\
\hline (Fungi) & Orthogonum giganteum Glaub, 1994 & $x$ & & $6 d$ \\
\hline Fungi & Saccomorpha clava Radtke, 1991 & $x$ & & $5 g$ \\
\hline (Fungi) & Saccomorpha guttulata Wisshak et al., 2018 & $x$ & $x$ & $5 h, i$ \\
\hline Bacteria & Scolecia serrata Radtke, 1991 & $x$ & $x$ & $6 \mathrm{~h}, \mathrm{i}$ \\
\hline
\end{tabular}


Table 3 Results of semi-quantitative analysis of microbioerosion traces at Mosselbukta and Bjørnøy-Banken. Abundances are categorized as very common $(++)$, common $(+)$, rare $(-)$ and very rare $(-)$.

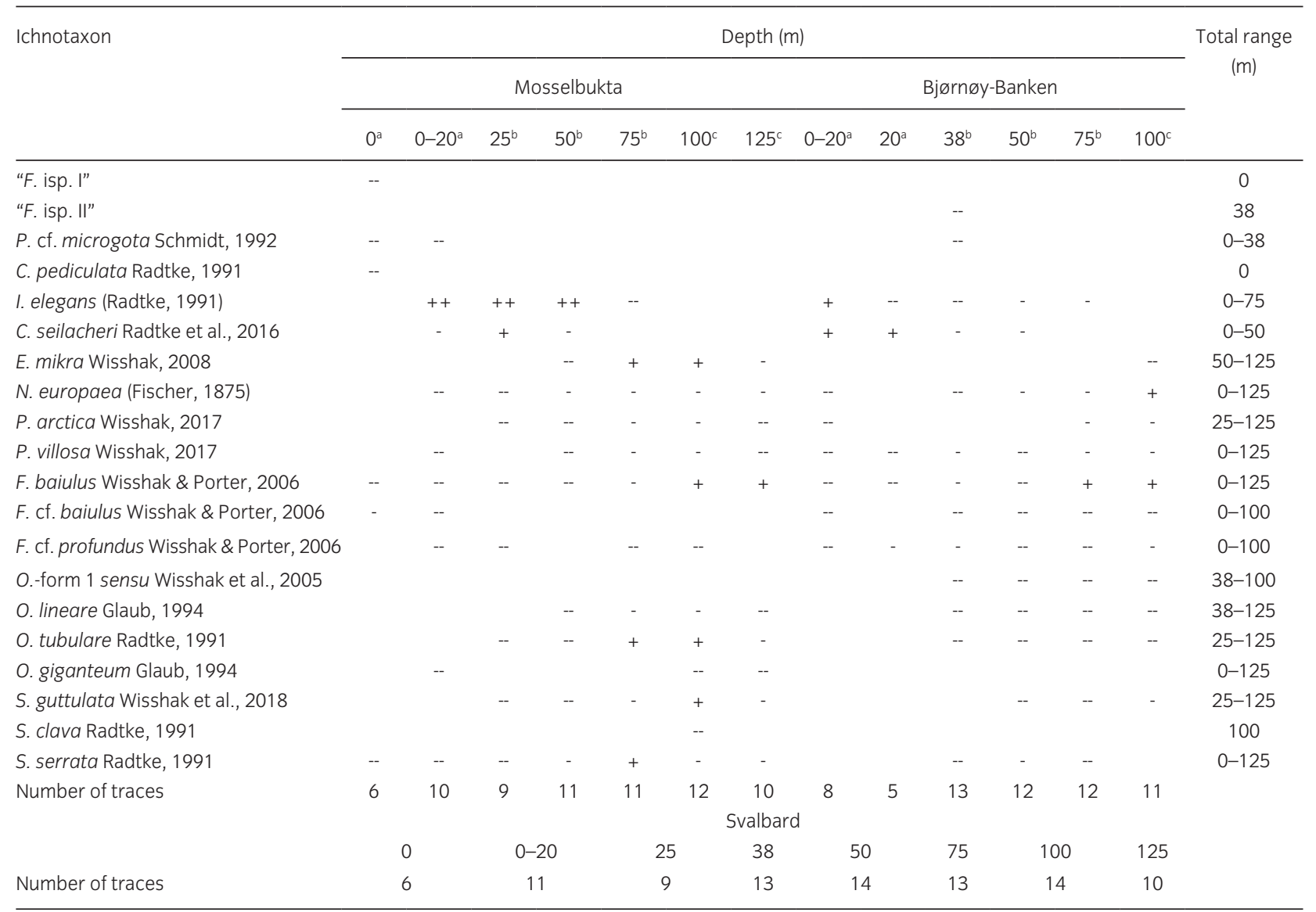

aEuphotic conditions. ${ }^{b}$ Dysphotic conditions. 'Aphotic conditions.

"Fascichnus isp. I". It has 100- $\mu$ m-long, uniformly thick tunnels with a diameter of 10-12 $\mu \mathrm{m}$, occasionally bifurcating with a $90^{\circ}$ angle. The trace shows a somewhat radiating appearance of the tunnels collapsed to the surface of the cast. Although the boring was too rare to provide a lot of details, we assumed a cyanobacterium as producer (Fig. 4a).

"Fascichnus isp. II". This trace grows from swelling with a $10 \mu \mathrm{m}$ diameter into a segmented and rarely twisted string with a maximum length of $75 \mu \mathrm{m}$ (Fig. 4b).

Planobola cf. microgota Schmidt, 1992. This spheroid to bulbous boring has similarities in size to P. microgota but lacks a latitudinal contact to the substrate surface via vertical tubules. Because further lack of characteristics prevented an assignment to a specific ichnospecies, we listed this ichnotaxon as P. cf. microgota (Fig. 4c).
Conchocelichnus seilacheri Radtke et al., 2016. Conchocelichnus seilacheri has a high morphological variability. Branchings are eitherwide, irregular and pancakelike with a diameter of 3-14 $\mu$ m or marked with almost perfectly shaped spherical swellings of up to $16 \mu \mathrm{m}$. The upright filament bushes of $C$. seilacheri have similarities to Fascichnus frutex (Radtke, 1991; Fig. 4g-i), complicating distinction of the two ichnospecies.

Nododendrina europaea (Fischer, 1875). Nododendrina europaea has occasionally thick galleries of up to $100 \mu \mathrm{m}$ in diameter and merging of single branches to a large plexus. At the Bjørnøy-Banken, striking long whips, originating from and around the single main chamber, were rarely observed (Fig. 4k, l).

Flagrichnus cf. baiulus Wisshak \& Porter, 2006. Flagrichnus cf. baiulus appears to lack the diagnostic long, thin, filamentous tube. Instead, the boring features thin 

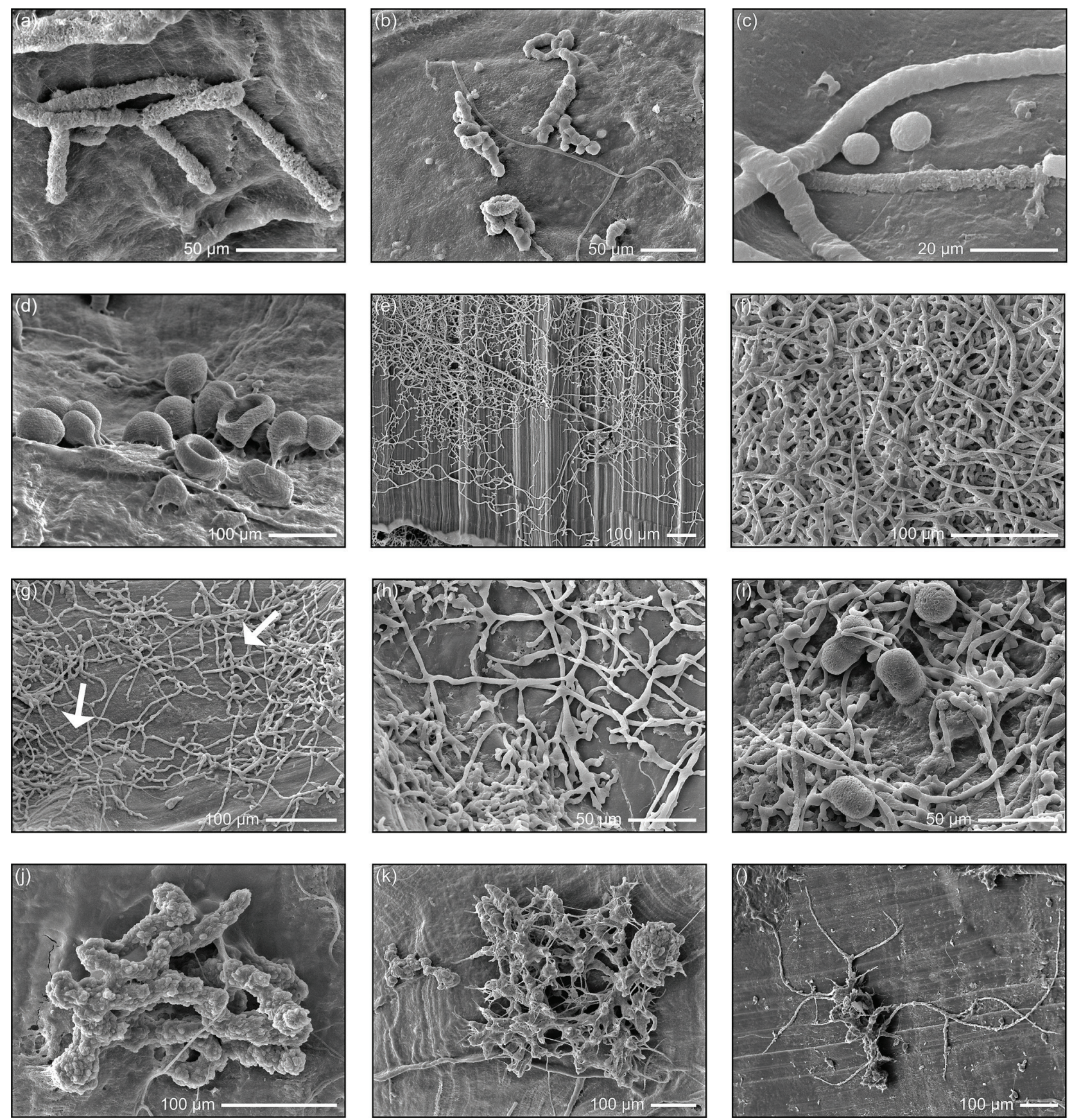

Fig. 4 Microborings inferred or assumed produced by (a)-(c) cyanobacteria, (d)-(g) chlorophytes, (g)-(i) rhodophytes, (j) sponges and (k)-(l) foraminiferans. (a) "Fascichnus isp. I" from the intertidal at Mosselbukta. (b) "Fascichnus isp. II" from $38 \mathrm{~m}$ water depth at Bjørnøy-Banken. (c) Planobola cf. microgota from 0 to $20 \mathrm{~m}$ water depth at Mosselbukta. (d) Cavernula pediculata from the intertidal at Mosselbukta. (e) Overview and (f) close-up of Ichnoreticulina elegans from $50 \mathrm{~m}$ water depth at Mosselbukta. (g) Ichnoreticulina elegans associated with Conchocelichnus seilacheri (white arrows) from $50 \mathrm{~m}$ water depth at Bjørnøy-Banken. (h) Conchocelichnus seilacheri from 0 to $20 \mathrm{~m}$ water depth at Mosselbukta. (i) Conchocelichnus seilacheri from $50 \mathrm{~m}$ water depth at Bjørnøy-Banken with prominent swellings. (j) Entobia mikra from $75 \mathrm{~m}$ water depth at Mosselbukta. (k) Nododendrina europaea from $100 \mathrm{~m}$ water depth at Mosselbukta and a small Entobia mikra to the left. (I) Nododendrina europaea from $95 \mathrm{~m}$ water depth at Bjørnøy-Banken with prominent long whips. 
filaments in the circumference. Typical sack-shaped cavities were occasionally connected with tunnels about 10 $\mu \mathrm{m}$ in length. In a few Bjørnøy-Banken samples, some of the traces show a rosette similar to the Cretaceous ichnogenus Dendrina Quenstedt, 1849, but they are much smaller in dimension (Fig. 5d). The unknown tracemaker may be identified based on Tribollet et al. (2011): their figure $4 \mathrm{~b}$ shows a fungus, whose morphology is similar to F. cf. baiulus (Fig. 5c, d).

Flagrichnus cf. profundus Wisshak \& Porter, 2006. This trace gradually tapers towards the end instead of a diagnosed basal-swelling leading to a deeply penetrating gallery, as described for F. profundus. The microsculpture is uneven and it does not penetrate as deep (Fig. 5e, f).
"Orthogonum-form 1" sensu Wisshak et al, 2005. This form comprises galleries 3-5 $\mu \mathrm{m}$ in diameter that run closely parallel to the substrate in a wavy manner for a few millimetres (Fig. 6a).

\section{Statistics of ichnodiversity and ichnodisparity}

Mardia's and Royston's Multivariate Normality Tests resulted in $p<0.05$ for ichnodiversity and multivariate normality was therefore rejected. An ANOSIM to test for significant differences between locations resulted in $R=0.10$ and a significance level of $0.15 \%$ (not significant). A second ANOSIM to test the factor "water depth" (the light regime being the principal underlying factor) resulted in $R=0.80$ and a significance level of $0.002 \%$
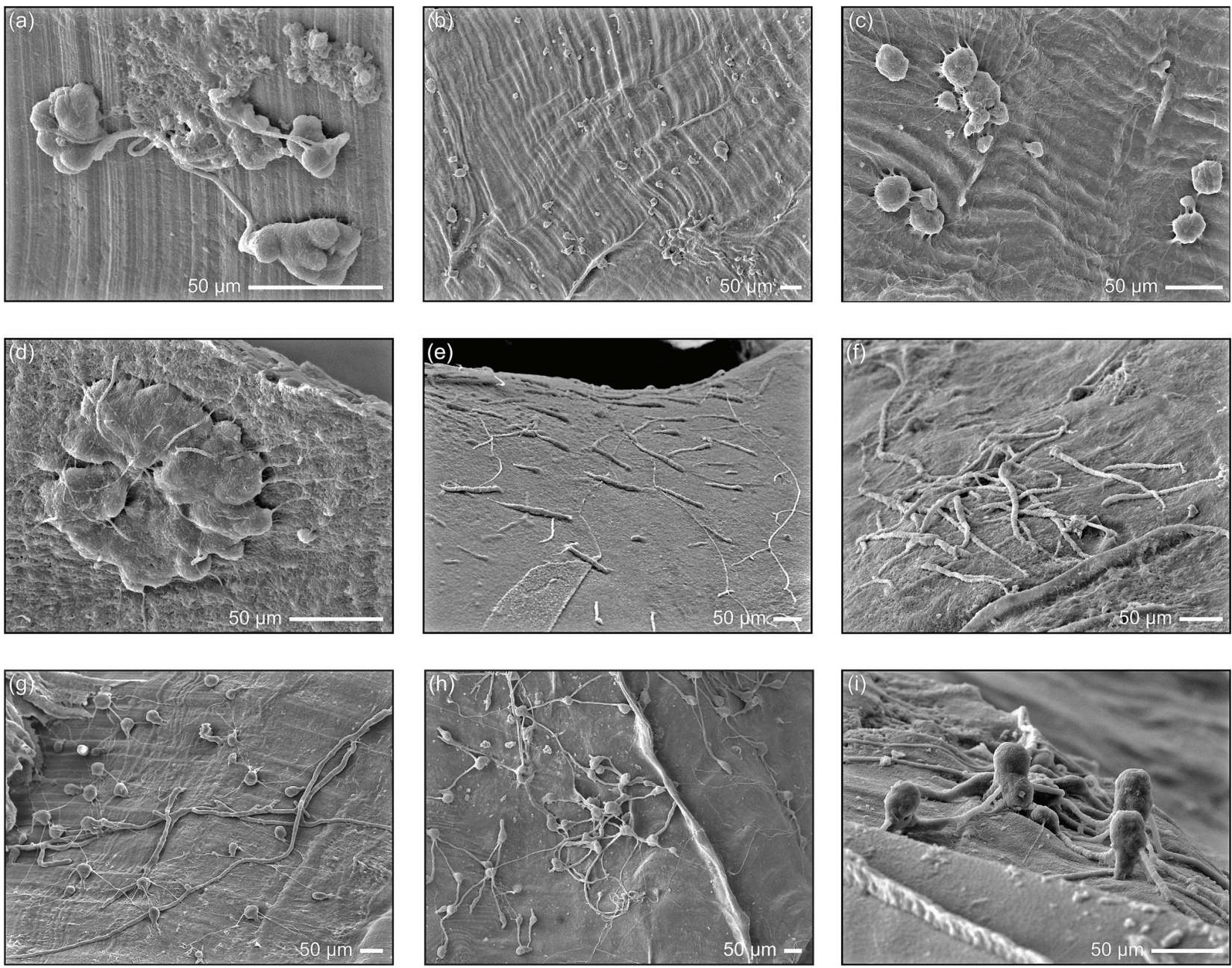

Fig. 5 Microborings inferred or assumed by fungi. (a) Close-up of Flagrichnus baiulus from 75 m water depth at Bjørnøy-Banken. (b) Initial Flagrichnus baiulus from the intertidal at Mosselbukta. (c) Flagrichnus cf. baiulus from the intertidal at Mosselbukta and (d) forming a rosette as observed in the intertidal at Bjørnøy-Banken. (e) Flagrichnus cf. profundus from 50 m water depth at Bjørnøy-Banken and from (f) 100 m water depth at Mosselbukta. (g) Saccomorpha clava from 100 m water depth at Mosselbukta. (h) Overview of Saccomorpha guttulata from 95 m water depth at Bjørnøy-Banken. (i) Saccomorpha guttulata from 75 m water depth at Bjørnøy-Banken. 

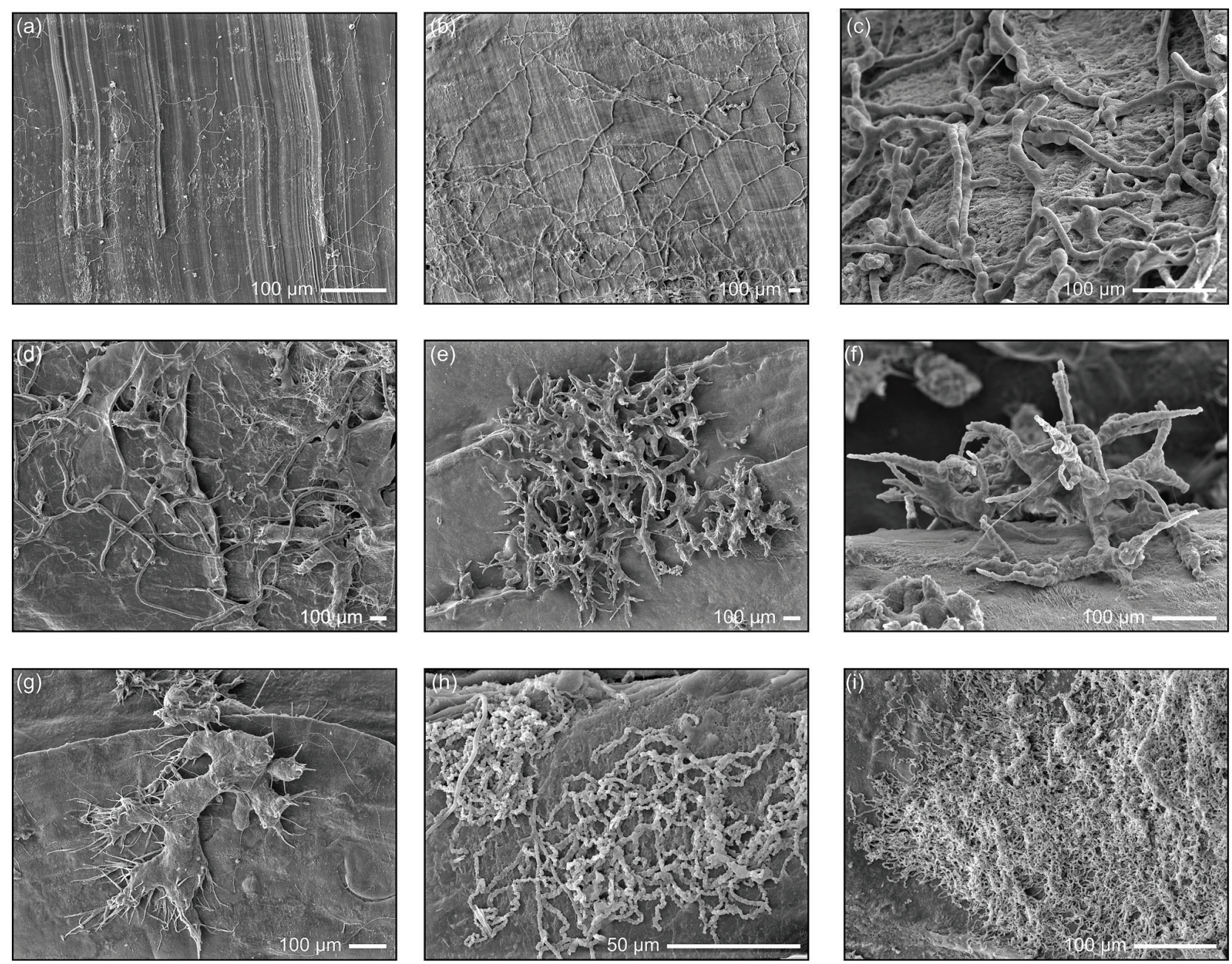

Fig. 6 Microborings produced by yet unknown organotrophic producers. (a) "Orthogonum-form 1" from 95 m water depth at Bjørnøy-Banken. (b) Orthogonum lineare from $100 \mathrm{~m}$ water depth at Mosselbukta. (c) Orthogonum tubulare from $100 \mathrm{~m}$ water depth at Mosselbukta. (d) Orthogonum giganteum from $100 \mathrm{~m}$ water depth at Mosselbukta. (e) A large Pyrodendrina arctica from $95 \mathrm{~m}$ water depth at Bjørnøy-Banken and (f) in angular view from 95 m water depth at Bjørnøy-Banken. (g) Pyrodendrina villosa from 95 m water depth at Bjørnøy-Banken. (h) Close-up of Scolecia serrata from 75 m water depth at Mosselbukta and (i) an overview from 50 m water depth at Bjørnøy-Banken.

(significant). An NMDS plot based on the Bray-Curtis similarity measure with the factor "location" showed that the microbioerosion trace assemblages in greater water depths cluster and were therefore similar to one another, whilst the shallow euphotic samples were outliers, reflecting dissimilarity (Fig. 7a). A cluster analysis with SIMPROF was computed to determine the number of significant clusters, which are four (Fig. 7c).

For the ichnodisparity analysis, each of the documented ichnogenera was assigned to one out of nine different groups (Table 4), following the categories of architectural designs in trace fossils established by Buatois et al. (2017).

For the ichnodisparity analysis, Mardia's and Royston's Multivariate Normality Tests resulted in $p<0.05$, so multivariate normality was rejected. An ANOSIM with the factor "location" computed $R=0.09$ and a significance level of $0.18 \%$ (not significant), whilst the factor "water depth" resulted in $R=-0.09$ and a significance level of $0.62 \%$ (not significant).

An NMDS plot based on the Bray-Curtis similarity measure (Fig. 7b) indicated that architectural designs are similar in greater water depths, whereas the shallowest stations are dissimilar. The SIMPROF cluster analysis (Fig. $7 \mathrm{~d})$ resulted in two to three main clusters: Mo_0 was fairly excluded from the rest, whereas the other two clusters split into several smaller ones (roughly corresponding to the photic zones), including a mix of samples from the different water depths and sites (Fig. 7d). 
(a)

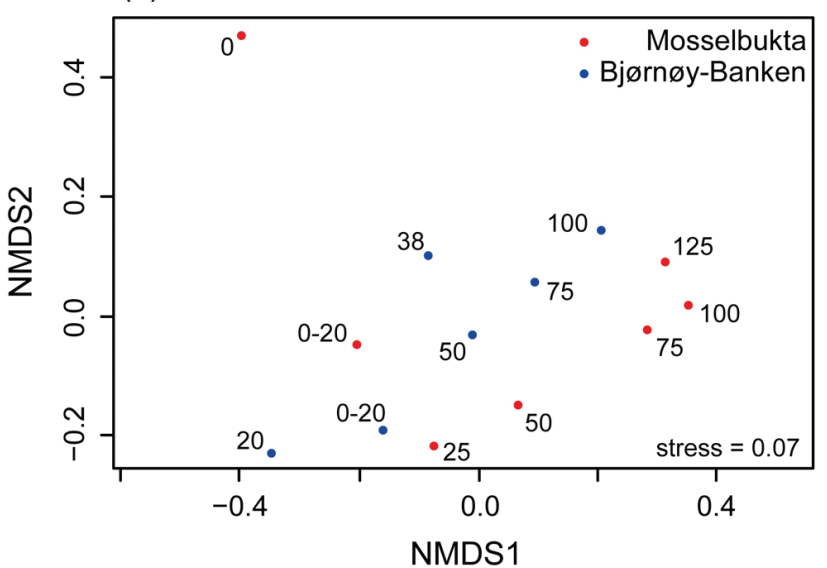

(c)

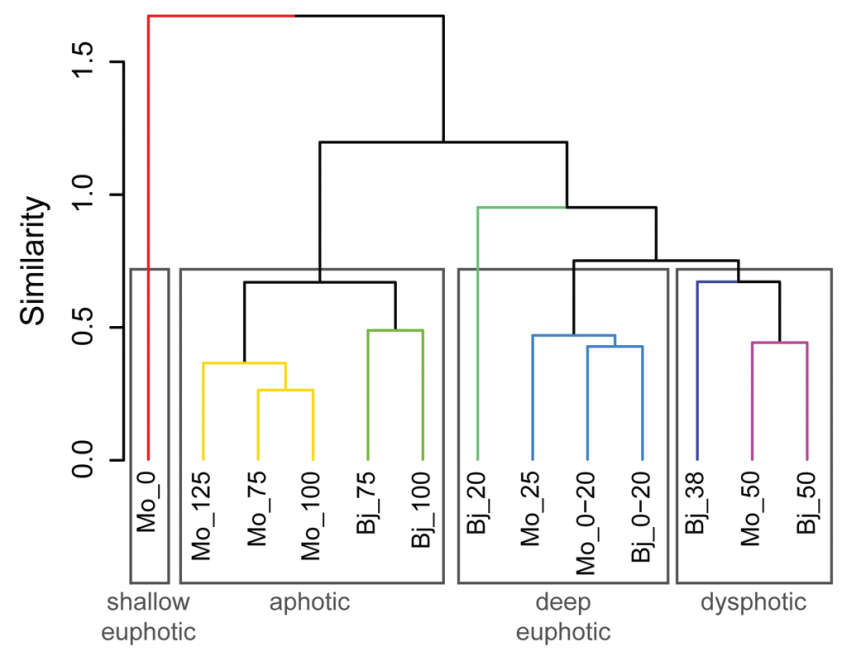

(b)

Ichnodisparity

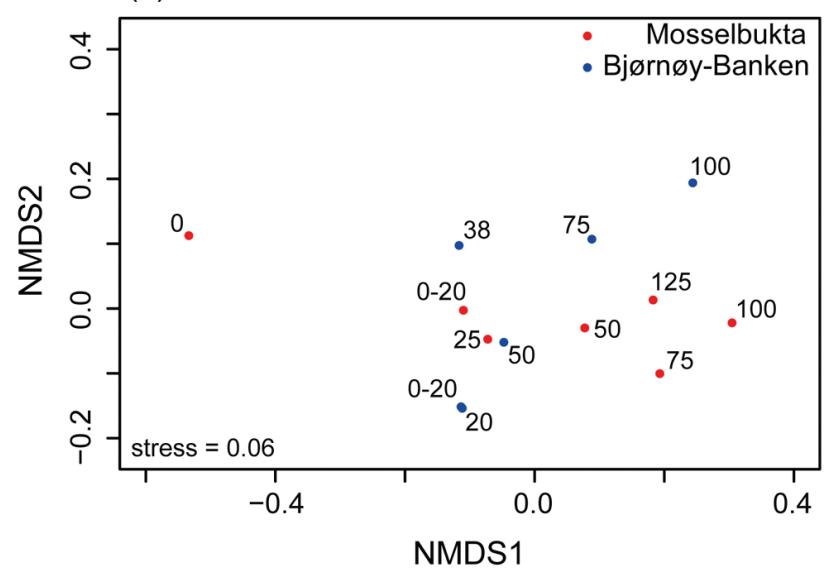

(d)

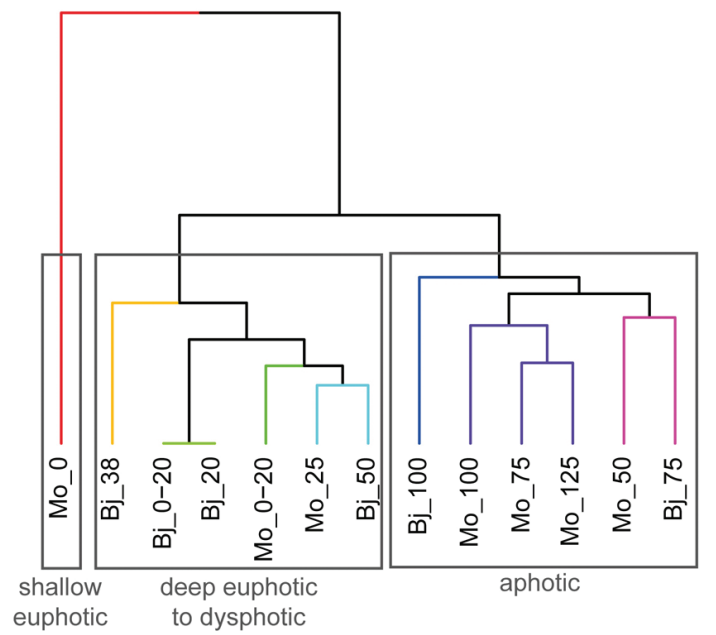

Fig. 7 Non-metric multidimensional scaling plots for the (a) ichnodiversity and (b) ichnodisparity at both study sites (data transformed with square root) and respective results of the cluster analyses with (c) and (d) similarity profile. For (c) ichnodiversity, the clustering correlates to four photic zones, shallow and deep euphotic, dysphotic, and aphotic, whereas (d) ichnodisparity, in contrast, shows a slightly less conclusive clustering in three photic zones.

\section{Indices of ichnodiversity and ichnodisparity}

According to the ichnodiversity indices, samples from deep euphotic water depths were dominated by single ichnotaxa ( $\lambda$ close to 1, I. elegans) and have therefore a low diversity $\left(I-\lambda^{\prime}\right.$ and $H^{\prime}\left(\log _{e}\right)$ close to 0$)$ and a general unevenness ( $J^{\prime}$ close to 0 ). Samples from dysphotic water depths had almost equally common ichnotaxa ( $\lambda$ close to $0)$, with high diversity $\left(1-\lambda^{\prime}\right.$ and $H^{\prime}\left(\log _{e}\right)$ close to 1 and higher, respectively) and high evenness ( $J^{\prime}$ close to 1$)$. This pattern is more pronounced in Mosselbukta (Table 5, Fig. 8a, b, d, e).

Ichnodiversity indices for the ichnodisparity concept demonstrate that Svalbard samples from the deep euphotic stations were marked by a single dominant group of architectural designs ( $\lambda$ close to 1 , branched tubular borings), as were the samples from $100 \mathrm{~m}$ water depth at Bjørnøy-Banken (dendritic and rosetted borings). Those sites had also a low diversity $\left(I-\lambda^{\prime}\right.$ close to 0 ) and unevenness ( $J^{\prime}$ close to 0 ). The 0 -m site at Mosselbukta and $20 \mathrm{~m}$ at Bjørnøy-Banken showed contrasting results; Mosselbukta samples showed that ichnotaxa were equally common ( $\lambda$ close to 0$)$ with a high diversity $\left(1-\lambda^{\prime}=1\right)$, although $H^{\prime}\left(\log _{e}\right)$ demonstrated that several architectural designs were found. Ichnodisparity indices were generally even $\left(J^{\prime}\right.$ closer to 1 than to 0 ) and marked by several groups, except for the deep euphotic stations at Mosselbukta (Table 5, Fig. 8d-f). 
Table 4 Ichnogenera categorized into nine different ichnodisparity groups, according to Buatois et al. (2017).

\begin{tabular}{|c|c|c|}
\hline Architectural designs & Ichnogenera & No. of ichnospecies \\
\hline 59-Cylindrical vertical to oblique borings & Flagrichnus & 3 \\
\hline 64-Globular to spherical borings & Planobola & 1 \\
\hline 66-Clavate-shaped borings & Cavernula & 1 \\
\hline 68-Branched tubular borings & Ichnoreticulina, Scolecia, Conchocelichnus ${ }^{a}$ & 3 \\
\hline 69-Non-camerate network borings & Orthogonum & 4 \\
\hline 71-Non-camerate boxwork borings & Entobia & 1 \\
\hline 74-Radial borings & Fascichnus & 2 \\
\hline 75-Dendritic and rosetted borings & Nododendrina, Pyrodendrina & 3 \\
\hline
\end{tabular}

${ }^{a}$ Conchocelichnus was not yet considered by Buatois et al. (2017) and is herein categorized as a branched tubular boring (group 68).

Table 5 Diversity indices for ichnodiversity and ichnodisparity of microborings at Mosselbukta and Bjørnøy-Banken, comprising ichnospecies richness S, Margalef's richness index $d$, Simpson index of dominance $\lambda$ and diversity $1-\lambda^{\prime}$, Shannon index $H^{\prime}\left(\log _{e}\right)$ and Pielou's evenness $J^{\prime}$.

\begin{tabular}{|c|c|c|c|c|c|c|}
\hline Sample & $\begin{array}{l}\text { Ichnospecies } \\
\text { richness, S }\end{array}$ & $\begin{array}{c}\text { Margalef's richness } \\
\text { index, } d\end{array}$ & $\begin{array}{c}\text { Simpson index of } \\
\text { dominance, } \lambda\end{array}$ & $\begin{array}{l}\text { Simpson index of } \\
\text { diversity, } 1-\lambda^{\prime}\end{array}$ & $\begin{array}{c}\text { Shannon index, } \\
H^{\prime}\left(\log _{e}\right)\end{array}$ & $\begin{array}{c}\text { Pielou's } \\
\text { evenness, } J^{\prime}\end{array}$ \\
\hline \multicolumn{7}{|c|}{ Ichnodiversity } \\
\hline Mo_0 & 6 & 1.85 & 0.47 & 0.57 & 1.17 & 0.65 \\
\hline Mo_0-20 & 10 & 1.30 & 0.97 & 0.03 & 0.12 & 0.05 \\
\hline Mo_25 & 9 & 1.14 & 0.82 & 0.18 & 0.35 & 0.16 \\
\hline Mo_75 & 11 & 1.70 & 0.23 & 0.77 & 1.69 & 0.71 \\
\hline Mo_100 & 12 & 1.80 & 0.20 & 0.80 & 1.80 & 0.72 \\
\hline Mo_125 & 10 & 1.79 & 0.44 & 0.56 & 1.30 & 0.56 \\
\hline Bj_0-20 & 8 & 1.31 & 0.47 & 0.53 & 0.86 & 0.41 \\
\hline Bj_20 & 5 & 0.85 & 0.79 & 0.21 & 0.45 & 0.28 \\
\hline Bj_38 & 13 & 3.08 & 0.17 & 0.85 & 2.01 & 0.78 \\
\hline Bj_75 & 12 & 2.20 & 0.48 & 0.52 & 1.23 & 0.50 \\
\hline Bj_100 & 11 & 1.82 & 0.34 & 0.66 & 1.37 & 0.57 \\
\hline \multicolumn{7}{|c|}{ Ichnodisparity } \\
\hline Mo_0 & 5 & 2.49 & 0.20 & 1.00 & 1.61 & 1.00 \\
\hline Mo_0-20 & 6 & 1.07 & 0.91 & 0.09 & 0.27 & 0.15 \\
\hline Mo_25 & 5 & 0.85 & 0.79 & 0.21 & 0.45 & 0.28 \\
\hline Mo_50 & 6 & 1.06 & 0.78 & 0.22 & 0.49 & 0.28 \\
\hline Mo_75 & 6 & 1.02 & 0.59 & 0.41 & 0.87 & 0.49 \\
\hline Mo_100 & 6 & 1.01 & 0.52 & 0.48 & 1.03 & 0.57 \\
\hline Mo_125 & 6 & 1.57 & 0.35 & 0.67 & 1.26 & 0.70 \\
\hline Bj_0-20 & 4 & 1.17 & 0.61 & 0.42 & 0.79 & 0.57 \\
\hline Bj_20 & 4 & 1.17 & 0.61 & 0.42 & 0.79 & 0.57 \\
\hline Bj_38 & 7 & 1.86 & 0.32 & 0.70 & 1.34 & 0.70 \\
\hline Bj_50 & 5 & 1.52 & 0.53 & 0.51 & 0.99 & 0.62 \\
\hline Bj_100 & 5 & 0.85 & 0.79 & 0.21 & 0.45 & 0.28 \\
\hline
\end{tabular}

aMo refers to Mosselbukta and Bj refers to Bjørnøy-Banken. The numbers are water depths. 


\section{CTD and photic zones}

(a)

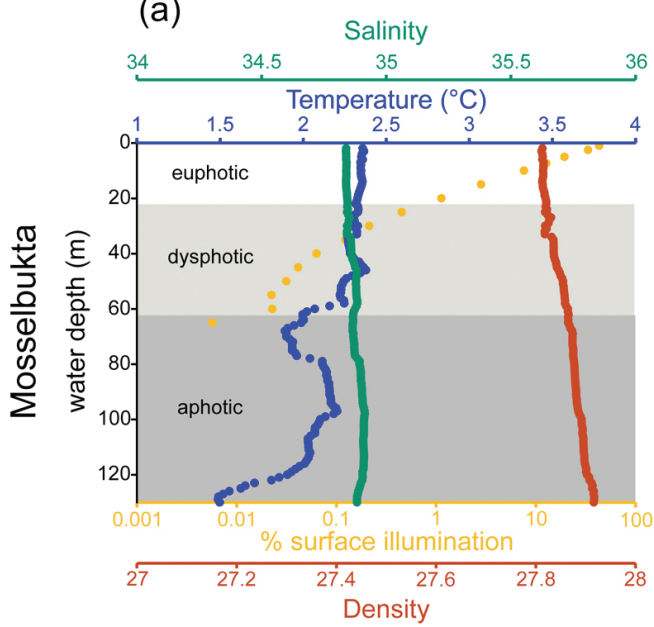

(d)

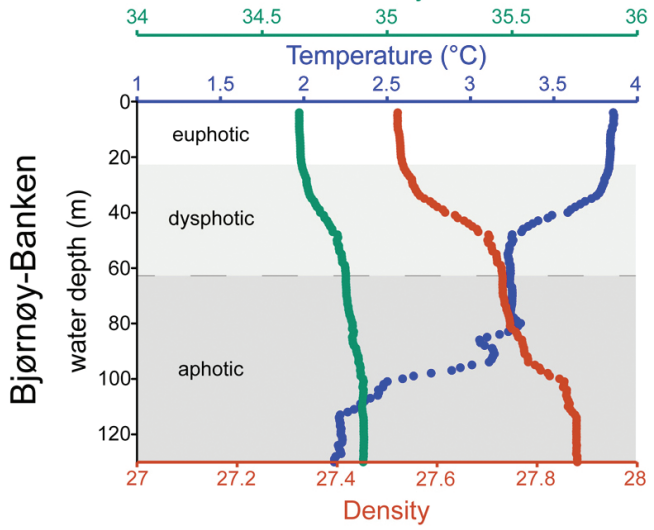

Ichnodiversity

(b)

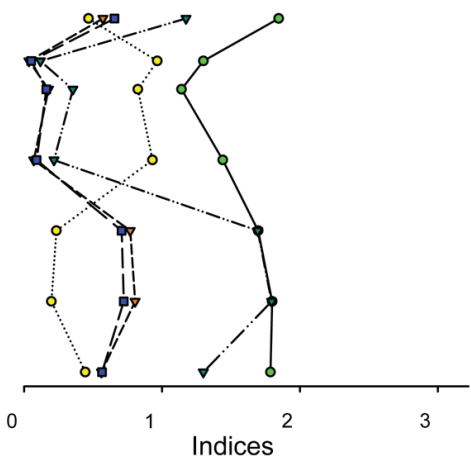

(e)

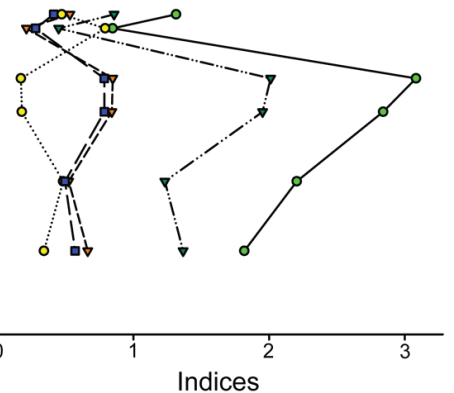

(c)

\section{Ichnodisparity}

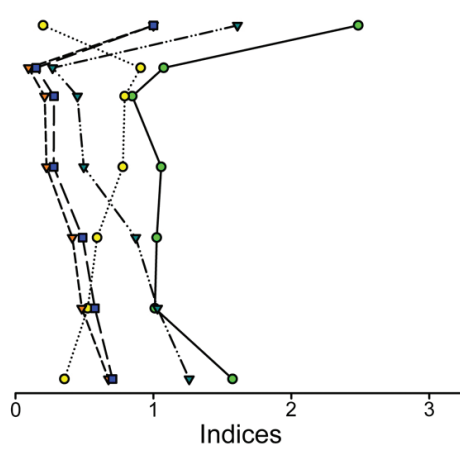

(f)
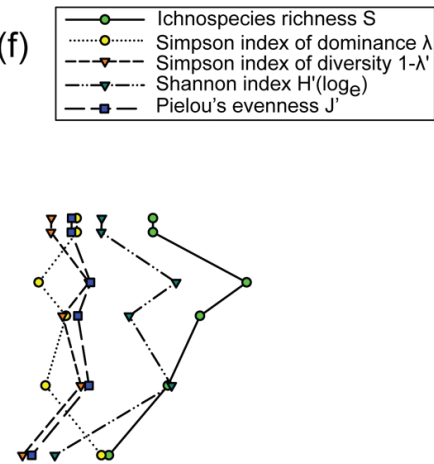

\begin{tabular}{lll}
\hline Indices $^{2}$ & 3
\end{tabular}

Fig. 8 Assessment of diversity indices for (b) and (e) ichnodiversity and (c) and (f) ichnodisparity across the bathymetrical transect (a)-(c) at Mosselbukta and (d)-(f) at Bjørnøy-Banken. Salinity, temperature and density data (Wisshak et al. 2017) were plotted with light intensities expressed as percent of the surface illumination in the logarithmic plots shown in (a) and (d) (light intensity data from Teichert et al. 2014). As no light intensity data were available for (d) Bjørnøy-Banken, the photic zonation in Mosselbukta is used as an approximation.

\section{Discussion}

\section{Bathymetric distribution}

Our inventory of microbioerosion traces obtained from polar balanids conforms to the general bathymetrical zonation pattern of microendolithic borings (e.g., Golubic et al. 1975; Schmidt 1992; Glaub 1994; Vogel et al. 2000; Glaub et al. 2002; Wisshak 2012), in which cyanobacterial borings were only identified in the deep euphotic zone, chloro- and rhodophyte borings dominated from the euphotic down to the dysphotic zone and traces by fungi occurred primarily in the aphotic zone. For practical reasons, we refer to photic zones, although during the polar night, they become largely irrelevant due to "aphotic" conditions throughout the water column.
However, ichnodiversity was found to be surprisingly low in the euphotic zone, where we would have expected a high diversity in borings produced by phototrophic microendoliths. As a result, an almost uniform total number of ichnotaxa was observed along the bathymetrical transect, with more traces of organotrophic microendoliths gradually compensating for the decrease of traces produced by phototrophic microphytes towards deeper waters (Table 3). Hence, whilst the ichnodiversity remains nearly constant, the composition changes with water depth. This finding contrasts the general trend that the highest variety of microbioerosion traces is usually observed in the euphotic zone, with a gradual decrease towards deeper waters (Wisshak 2012). We explain this discrepancy with strong environmental fluctuations in the intertidal zone 
and upper water column (Fig. 8a, d; Glaub et al. 2007; Golubic et al. 2016). The upper part of polar oceans is influenced by extreme seasonal variations, primarily in light levels and temperature, periods of sea ice cover and consequential meltwater influx (Figs. 2, 8; Wiencke et al. 2006). Furthermore, we assume that drift ice piling up along the shore during winter/spring prohibits balanids from growing old and becoming intensely bioeroded before the ice abrades them, which results in colonization and bioerosion only by opportunistic microendoliths and allowing the establishment of only immature, lowdiversity microboring trace assemblages. In deeper water, light levels are low throughout the year and variations of temperature and salinity are less extreme (Fig. 8a, d), providing stable environmental conditions for organotrophic microendoliths in the dysphotic and aphotic zones. This interpretation is supported by the NMDS plots, cluster analyses (Fig. 7) and ichnodiversity indices (Fig. 8): the shallow euphotic zone, in particular the intertidal zone, is dissimilar to the deeper euphotic zone and beyond. Deeper samples can be subdivided into distinct clusters, representing deeper euphotic, dysphotic and aphotic conditions.

The observed bathymetrical distribution pattern and ANOSIM results indicate that water depth, affecting the light regime, is the major factor for the establishment of bioerosion trace assemblages in balanids of the polar waters of Svalbard. In contrast, the site factor was much less relevant, with Mosselbukta and Bjørnøy-Banken yielding almost the same suite of ichnotaxa at equivalent depth stations (Table 3).

\section{Intensity of microbioerosion}

Comparatively greater abundances of various microborings in Mosselbukta possibly reflect more favourable environmental conditions. These are also reflected in the presence of rhodoliths beds at intermediate water depths, which have been demonstrated to increase benthic diversity and abundance, owing to an increase in habitat diversity provided by the bio-engineering crustose rhodophyte Lithothamnion glaciale Kjellman, 1883 (Teichert 2014; Wisshak et al. 2017; Schoenrock et al. 2018; Wisshak et al. 2019). Mosselbukta is better protected from currents, whilst a strong hydrodynamic regime and the nearby Polar Front with colder surface temperatures persist at Bjørnøy-Banken (Henrich et al. 1997; Wisshak et al. 2017; Wisshak et al. 2019). Water masses at Mosselbukta and around Bjørnøy-Banken also differ in turbidity, with the strong tidal currents at Bjørnøy-Banken leading to resuspension of sediment and food particles following every flood tide. This also results in less light reaching the seafloor, as evident from PAR data logged during two lander deployments at Mosselbukta and Bjørnøy-Banken (Wisshak et al. 2019). These factors appear to promote more intense bioerosion in Mosselbukta compared with Bjørnøy-Banken, resulting in a greater abundance of microborings in Mosselbukta but not a significant variation in ichnodiversity (Tables 2, 3).

\section{Ichnodiversity versus ichnodisparity}

Whilst ichnodiversity reflects the number of species (ichnotaxonomic richness), ichnodisparity is "a measure of the variability of morphologic plans" (Buatois et al. 2017:104) and is based on a classification into categories of architectural designs. Within each of these architectural groups present in our data set, there may be different ichnospecies (Table 4). A high ichnodiversity does not necessarily mean that the ichnodisparity is also high (see figure 80 in Buatois et al. 2017); likewise, the same degree of ichnodisparity does not mean that the same architectural designs are present. The application of the ichnodisparity concept as a complementing approach did not yield clear differences between the two sites or between the various water depths (low $R$ values and significance levels). The ichnodisparity indices (Fig. 8c, f) and the NMDS plot (Fig. 7b) draw a similar picture, with only the intertidal station in Mosselbukta showing a different signature that is most likely a result of the low ichnodiversity in the initial microboring trace assemblage (see discussion above). The cluster analysis (Fig. 7c, d) for ichnodiversity and ichnodisparity, however, differed in that the ichnodiversity showed four distinct clusters related to the different photic zones, whereas the architectural groups showed three distinct clusters, which are related to "shallow euphotic", "deep euphotic to dysphotic" and "aphotic" conditions. The diversity in the architectural designs and, therefore, boring behaviour by microendoliths differs to some degree throughout the bathymetric transect, but not between the different sites (Fig. 7d). The clustering is statistically not significant, however, probably reflecting a combination of microborings by phototrophs and organotrophs within the different groups. Categories including ichnotaxa by phototrophs occurred primarily in the photic zone (e.g., "globular to spherical borings", "radial borings"), but as the bacterial ichnogenus Scolecia belongs together with Ichnoreticulina and Conchocelichnus to "branched tubular borings", the design persists throughout the bathymetric transect.

\section{Comparison with lower latitudes}

Putting our catalogue of the Svalbard microborings in the context of global distribution patterns, we compared our findings primarily with two studies with a comparable 
bathymetrical transect from lower latitudes in the North Atlantic: the cold-temperate Kosterfjord in Sweden and the warm-temperate Azores Archipelago (further results of ichnodiversity studies in various settings were summarized by Wisshak et al. [2011], Table 3). This comparison indicates that the Svalbard ichnotaxa record complies with the overall bathymetrical decrease of microboring ichnodiversity towards higher latitudes (Wisshak 2006; Wisshak et al. 2011). Although we here compare natural substrates with two-year experimental exposures and despite Arctic balanids being mostly older than the analysed platforms, by far the highest ichnodiversity was detected in the Azores, a warm-temperate setting with apparently more favourable environmental conditions for microbioerosion (Wisshak et al. 2011). At the cold-temperate Kosterfjord site, temperatures are colder than in the Azores and have a stronger seasonal fluctuation. Moreover, the water is more turbid and the photic zonation is considerably condensed, which results in a reduced ichnodiversity (Wisshak 2006). Svalbard has the lowest temperatures and most strongly limited light regime, combined with the strongest seasonal fluctuations, and this is reflected in the lowest ichnodiversity among the three sites.

As far as the spectrum of inferred or assumed microendolithic trace-makers is concerned, 20 microbioerosion traces were documented in Svalbard waters. In contrast, nearly twice as many (37) were encountered on experimental settlement platforms in the Azores, including 11 cyanobacterial microborings, seven traces by chlorophytes, eight of fungal origin and 11 other organotrophic microborings (Wisshak et al. 2011). In the Kosterfjord, Sweden, an intermediate ichnodiversity of 26 different traces on three different substrate types was recorded. On the experimental substrates, seven of the investigated traces were produced by cyanobacteria, four by chlorophytes, six by fungi and four by unidentified organisms (Wisshak 2006). Seven microborings at the Svalbard sites were attributed to phototrophic microendoliths (three cyanobacteria, two chlorophytes, one rhodophyte trace-maker). This comparison indicates that it is chiefly the depletion in microalgae and cyanobacteria that is reflected in the low ichnodiversity.

The polar night, in combination with a condensed photic zonation during the polar day and transitional months, imposes significant limitations for these phototrophic organisms. In consequence, traces produced by low-light specialists were found most abundant in the phototrophic borer spectrum, specifically I. elegans (produced by the chlorophyte Ostreobium quekettii Bornet $\delta$ Flahault, 1889) and C. seilacheri (produced by bangialean rhodophytes). Apart from the seasonal availability of light for photosynthesis (e.g., Schmidt \& Freiwald 1993;
Zacher et al. 2009), the distribution of microphytes is commonly limited by low temperatures, with only a few specialists coping well with the harsh Arctic conditions. Few studies of marine Arctic microalgae (Wulff et al. 2009) have been undertaken, but they all show that abundance and diversity are generally poor (Garbary 2001), with only a few endemic species in the Arctic (Wulff et al. 2009). Polar species have different metabolic strategies to adapt to low light availability and low temperatures, such as red algae that accumulate floridean starch grains from food remnants during the polar day to adapt to the polar night (e.g., Woelkerling 1990; Freiwald \& Henrich 1994; Viola et al. 2001). The different strategies allow perennial algae to survive throughout the polar night (Lüning 1985; Heimdal 1989; Gómez et al. 2009; McMinn \& Martin 2013). The question of how specific microborers adapt to the polar environment has received little attention and is beyond the scope of the present study. However, euendoliths are generally relatively robust with respect to environmental fluctuations as they are buffered in the microenvironment of their borings (Vogel \& Glaub 2004) and could therefore also be expected to survive the polar night.

Light availability is irrelevant for organotrophs, and as the temperature becomes more stable towards greater water depths, the conditions are less extreme. Organotrophs thrive in cold environments at all water depths and dominate in the aphotic zone. Those circumstances influence not only the abundance and diversity of microborings but also the dominant ichnospecies in the various biogeographic realms.

Samples from the deep euphotic zone were dominantly bored by phototrophic microendoliths. In Svalbard, mainly $C$. seilacheri or I. elegans occurred, whilst the intertidal at Kosterfjord was primarily colonized by Cavernula pediculata and Fascichnus ichnospecies. There, the shallow euphotic zone was characterized by C. pediculata, Eurygonum nodosum, Fascichnus dactylus and Orthogonum fusiferum (Wisshak 2006). The most common ichnotaxa at the Azores at shallow water depths were E. nodosum and Scolecia filosa, both produced by cyanobacteria (Wisshak et al. 2011).

The dysphotic zone in Svalbard was densely colonized and had the highest ichnodiversity, with I. elegans as the most dominant ichnotaxon. In the Kosterfjord dysphotic zone, Flagrichnus ichnospecies, Saccomorpha clava and Orthogonum lineare were prominent ichnotaxa, with the same trend in aphotic depths (Wisshak 2006). The aphotic zone in Svalbard was dominated by fungal microborings, e.g., Orthogonum tubulare or S. guttulata. Nododendrina europaea and other borings by unknown producers, such as the Pyrodendrina ichnospecies, resulted in a comparatively high ichnodiversity (Table 3). Ichnoreticulina elegans 
was dominant in deep euphotic to dysphotic water samples from the Azores, whereas S. clava and $N$. europaea were common at dysphotic to aphotic depths of the Azorean water column (Wisshak et al. 2011).

This work shows that in spite of the similarity between deep-water conditions at low latitudes and conditions at high latitudes, some ichnotaxa common in warm- and cold-temperate realms-such as the cyanobacterial ichnotaxa E. nodosum and S. filosa and the chlorophyte microborings in the ichnogenus Rhopalia-were not observed in the polar region under investigation. Ichnotaxa so far exclusive to the cold-temperate and polar realm are F. baiulus, Entobia mikra, N. europaea and S. guttulata (Wisshak 8 Porter 2006; Bromley et al. 2007; Wisshak 2008; Wisshak et al. 2018, respectively); all of them assumingly bored by fungi, foraminifera and sponges. Orthogonum-form 1 was until now also only described from the Kosterfjord and is therefore also restricted to cold-temperate and polar regions (Wisshak 2006). Saccomorpha clava is usually a ubiquitous fungal ichnotaxon (e.g., Wisshak 2006; Wisshak et al. 2011; Färber et al. 2015), but only one single colony was observed in Mosselbukta, whilst we commonly found $S$. guttulata as a substitute of this trace. Fascichnus isp. I, II or Flagrichnus cf. baiulus are informally described and referred to as "cf." in the present study, because they show "undescribed" features or an adapted boring behaviour and are thus different to the original diagnosis. Those "adaptations" may be effects of the limiting environmental parameters.

\section{Conclusions}

We address the lack of comprehensive Arctic (micro)bioerosion research by presenting a catalogue of 20 different ichnotaxa that we have recorded in more than 100 balanid samples from euphotic to aphotic depths from two polar carbonate factories in Svalbard waters. A remarkably low ichnodiversity was observed in shallow euphotic waters, which is herein explained by limitations in the availability of multiannual balanids as substrate and by the harsh environmental conditions characterized by a lack of PAR during the polar night, low and fluctuating temperatures and the influence of sea ice. Light availability is the most significant factor for the establishment of different microbioerosion trace assemblages in different water depths. The extreme light regime and low temperatures led to a depletion of particularly the phototrophic microborer spectrum that lacks several of the "usual suspects" among the ichnotaxa commonly encountered in lower latitudes. Overall, this results in a comparatively low ichnodiversity that accords with a general decrease in ichnodiversity towards higher latitudes. More studies, considering different types of substrate, further polar sites in both hemispheres and studies of the bioerosion rate, are needed to gain a more complete picture of the role of bioerosion in polar carbonate factories.

\section{Acknowledgements}

We thank the crew of the RV Maria S. Merian on the MSM55 cruise and the GEOMAR JAGO team for helping to recover our samples. We acknowledge Alexander Bartholomä (Senckenberg am Meer, Wilhelmshaven) for providing bathymetry data for Fig. 1 and Nicol Mahnken (Senckenberg am Meer, Wilhelmshaven) for her support during sample preparation. We also thank the reviewers Ana Santos and Nicholas Minter for their constructive comments and suggestions on the manuscript that helped us to improve it.

\section{Disclosure statement}

The authors report no conflict of interest.

\section{Funding}

This work was funded by the German Research Foundation (DFG) under grant WI 3754/3-1 and the RV Maria S. Merian MSM55 cruise that provided the studied samples was funded by the DFG in concert with the Leitstelle Deutsche Forschungsschiffe. Open access fees for this publication were funded by the University of Bremen, Germany.

\section{References}

Aitken A.E. \& Risk M.J. 1988. Biotic interactions revealed by macroborings in Arctic bivalve molluscs. Lethaia 21, 339-350, doi: 10.1111/j.1502-3931.1988.tb01762.x.

Akpan E.B. \& Farrow G.E. 1985. Shell bioerosion in high-latitude low-energy environments: firths of Clyde and Lorne, Scotland. Marine Geology 67, 139-150, doi: 10.1016/0025-3227(85)90152-5.

Barnes H. \& Barnes M. 1954. The general biology of Balanus balanus (L.) Da Costa. Oikos 5, 63-76.

Barnes H. \& Powell H.T. 1953. The growth of Balanus balanoides (L.) and B. crenatus Brug. under varying conditions of submersion. Journal of the Marine Biological Association of the United Kingdom 32, 107-127, doi: 10.1017/ S0025315400011450.

Bornet E. \& Flahault C. 1889. Sur quelques plantes vivant dans le test calcaire des mollusques. (About some plants living in the calcareous shell of molluscs.) Bulletin de la Societe Botanique de France 36, 147-179, doi: 10.1080/00378941.1889.10835893.

Bromley R.G. 2004. A stratigraphy of marine bioerosion. In D. Mclllroy (ed.): The application of ichnology to 
palaeoenvironmental and stratigraphic analysis. Pp. 455-479. London: Geological Society.

Bromley R.G. \& Hanken N.-M. 1981. Shallow marine bioerosion at Vardø, Arctic Norway. Bulletin of the Geological Society of Denmark 29, 103-109.

Bromley R.G., Wisshak M., Glaub I. \& Botquelen A. 2007. Ichnotaxonomic review of dendriniform borings attributed to foraminiferans: Semidendrina igen. nov. In W. Miller (ed.): Trace fossils: concepts, problems, prospects. Pp. 518-530. Amsterdam: Elsevier Science.

Bruguière J.G. 1789. Encyclopédie méthodique ou par ordre de matières. Histoire naturelle des vers. (Methodical encyclopedia by order of subject matter. Natural history of worms.) Paris: Panckoucke.

Buatois L.A., Wisshak M., Wilson M.A. \& Mángano M.G. 2017. Categories of architectural designs in trace fossils: a measure of ichnodisparity. Earth-Science Reviews 164, 102-181, doi: 10.1016/j.earscirev.2016.08.009.

Färber C., Wisshak M., Pyko I., Bellou N. \& Freiwald A. 2015. Effects of water depth, seasonal exposure, and substrate orientation on microbial bioerosion in the Ionian Sea (eastern Mediterranean). PLoS One 10, e0126495, doi: 10.1371/journal.pone.0126495.

Feussner K.-D., Skelton P.A., South G., Alderslade P. \& Aalbersberg W. 2004. Ostreobium quekettii (Ostreobiaceae: Chlorophyceae) invading the barnacle Acasta sp. (Pendunculata: Acastinae), endozoic in the octocoral Rumphella suffruticosa (Alcyonacea: Gorgoniidae) from Fiji, South Pacific. New Zealand Journal of Marine and Freshwater Research 38, 87-90, doi: 10.1080/00288330.2004.9517220.

Feyling-Hanssen R.W. 1953. The barnacle Balanus balanoides (Linne, 1766) in Spitsbergen. Norsk Polarinstitutt Skrifter 98. Oslo: Norwegian Polar Institute.

Fischer M.P. 1875. D'un type de sarcodaires. (About a species of protoplasmic organisms.) Journal de Zoologie 4, 530-533.

Freiwald A. \& Henrich R. 1994. Reefal coralline algal buildups within the Arctic Circle: morphology and sedimentary dynamics under extreme environmental seasonality. Sedimentology 41, 963-984.

Garbary D.J. 2001. Biogeography of marine algae. In: Encyclopedia of life sciences. Hoboken, NJ: John Wiley \& Sons. Doi: 10.1038/npg.els.0000312.

Glaub I. 1994. Mikrobohrspuren in ausgewählten Ablagerungsräumen des europäischen Jura und der Unterkreide (Klassifikation und Palökologie). (Microboring traces in selected depositional environments of the European Jurassic and Lower Cretaceous [classification and paleoecology].) Frankfurt: Senckenberg Nature Research Society.

Glaub I., Gektidis M. \& Vogel K. 2002. Microborings from different North Atlantic shelf areas-variability of the euphotic zone extension and implications for paleodepth reconstructions. Courier Forschungsinstitut Senckenberg 237, 25-37.

Glaub I., Golubic S., Gektidis M., Radtke G. \& Vogel K. 2007. Microborings and microbial endoliths: geological implications. In W. Miller (ed.): Trace fossils: concepts, problems, prospects. Pp. 368-381. Amsterdam: Elsevier.

Golubic S., Campbell S.E., Lee S.-J. \& Radtke G. 2016. Depth distribution and convergent evolution of microboring organisms. PalZ 90, 315-326, doi: 10.1007/ s12542-016-0308-6.

Golubic S., Perkins R.D. \& Lukas K.J. 1975. Boring microorganisms and microborings in carbonate substrates. In R.W. Frey (ed.): The study of trace fossils: a synthesis of principles, problems, and procedures in ichnology. Pp. 229-259. Berlin: Springer.

Gómez I., Wulff A., Roleda M.Y., Huovinen P., Karsten U., Quartino M.L., Dunton K. \& Wiencke C. 2009. Light and temperature demands of marine benthic microalgae and seaweeds in polar regions. Botanica Marina 52, 593-608, doi: 10.1515/BOT.2009.073.

Greenacre M. \& Primicerio R. 2013. Multivariate analysis of ecological data. Bilbao: BBVA Foundation.

Hammer Ø. \& Harper D.A. 2008. Paleontological data analysis. Oxford: Blackwell Publishing.

Hanken N., Uchman A. \& Jakobsen S.L. 2012. Late Pleistocene-early Holocene polychaete borings in NE Spitsbergen and their palaeoecological and climatic implications: an example from the Basissletta area. Boreas 41, 42-55, doi: 10.1111/j.1502-3885.2011.00223.x.

Heimdal B.R. 1989. Arctic ocean phytoplankton. In Y. Herman (ed.): The Arctic seas: climatology, oceanography, geology, and biology. Pp. 193-222. Boston, MA: Springer.

Henrich R., Freiwald A., Bickert T. \& Schäfer P. 1997. Evolution of an Arctic open-shelf carbonate platform, Spitsbergen Bank (Barents Sea). In N.P. James \& J.A.D. Clarke (eds.): Cool-water carbonates. Pp. 163-181. McLean, VA: SEPM Society for Sedimentary Geology. doi: 10.2110/pec.97.56.0163.

Kjellman F.R. 1883. The algae of the Arctic sea: a survey of the species, together with an exposition of the general characters and the development of the flora. Kongliga Svenska Vetenskaps-Akademiens Handlingar 20. Stockholm: Royal Swedish Academy of Sciences.

Korkmaz S., Goksuluk D. \& Zararsiz G. 2014. An R package for assessing multivariate normality. The R Journal 6, $151-162$.

Linnaeus C. 1758. Systema naturae per regna tria naturae, secundum classes, ordines, genera, species, cum characteribus, differentiis, synonymis, locis. (System of nature through the three kingdoms of nature, according to classes, orders, genera and species, with characters, differences, synonyms, places.) Vol. 1. 10th edn. Stockholm: L. Salvii.

Lüning K. 1985. Meeresbotanik: Verbreitung, Ökophysiologie und Nutzung der marinen Makroalgen. (Marine botany: distribution, ecophysiology and usage of the marine macro-algae.) Stuttgart: Thieme.

Luther G. 1987. Seepocken der deutschen Küstengewässer. (Barnacles of the German coastal waters.) Helgoländer Meeresuntersuchungen 41, 1-43, doi: 10.1007/BF02365098.

McMinn A. \& Martin A. 2013. Dark survival in a warming world. Proceedings of the Royal Society of London 280, 201-229, doi: 10.1098/rspb.2012.2909.

Müller O.F. 1776. Zoologix Danicae Prodromus, seu Animalium Danix et Norvegiae indigenarum characteres, nomina, et synonyma imprimis popularium. (Danish history of zoology, or the native characters of Danish and Norwegian animals, names and population synonyms.) Copenhagen: Hallageri. 
Neumann A.C. 1966. Observations on coastal erosion in Bermuda and measurements of the boring rate of the sponge Cliona lampa. Limnology and Oceanography 11, 92-108, doi: 10.4319/lo.1966.11.1.0092.

NOAA Global Monitoring Laboratory 2020. Sunset table for 2016. NOAA Solar calculator. US National Oceanic and Atmospheric Administration. Accessed on the internet at https://www.esrl.noaa.gov/gmd/grad/solcalc/ on 21 July 2020.

Norwegian Meteorological Institute 2019. Norwegian Ice Service. Accessed on the internet at http://polarview.met. no/ (now https://cryo.met.no/en/latest-ice-charts) on 10 July 2019.

Oksanen J., Blanchet F.G., Friendly M., Kindt R., Legendre P., McGlinn D., Minchin P.R., O'Hara R.B., Simpson G.L., Solymos P., Henry M., Stevens H., Szoecs E. \& Wagner H. 2018. Vegan: Community Ecology package. In R package version 2.5-3. Accessible on the internet at https:// CRAN.R-project.org/package=vegan.

Quenstedt F.A. 1849. Petrefaktenkunde Deutschlands. Erster Band. Cephalopoden. (Palaeontology of Germany. Vol. 1. Cephalopods.) Tübingen: Fues, Ludwig Friedrich.

Radtke G. 1991. Die mikroendolithischen Spurenfossilien im Alt-Tertiär West-Europas und ihre palökologische Bedeutung. (The microendolithic trace fossils in the Early Tertiary of western Europe and their palaeoecological significance.) Frankfurt: Senckenberg Nature Research Society.

Radtke G., Campbell S.E. \& Golubic S. 2016. Conchocelichnus seilacheri igen. et isp. nov., a complex microboring trace of bangialean rhodophytes. Ichnos 23, 228-236, doi: 10.1080/10420940.2016.1199428.

$\mathrm{R}$ Core Team 2018. R: a language and environment for statistical computing. Vienna: R Foundation for Statistical Computing.

Schmidt H. 1992. Mikrobohrspuren ausgewählter Faziesbereiche der tethyalen und germanischen Trias (Beschreibung, Vergleich und bathymetrische Interpretation). (Microboring traces in selected facies areas of the Tethyan and Germanic Triassic [Description, comparison and bathymetric interpretation].) Frankfurt: Frankfurter Geowissenschaftliche Arbeiten.

Schmidt H. \& Freiwald A. 1993. Rezente gesteinsbohrende Kleinorganismen des norwegischen Schelfs. (Recent rock boring microorganisms of the Norwegian shelf.) Natur und Museum 123, 149-155.

Schoenrock K., Vad J., Muth A., Pearce D.M., Rea B.R., Schofield J.E. \& Kamenos N.A. 2018. Biodiversity of kelp forests and coralline algae habitats in southwestern Greenland. Diversity 10, article no. 117, doi: 10.3390/ d 10040117.

Teichert S. 2014. Hollow rhodoliths increase Svalbard's shelf biodiversity. Scientific Reports 4, article no. 6972, doi: 10.1038/srep06972.

Teichert S., Woelkerling W., Rüggeberg A., Wisshak M., Piepenburg D., Meyerhöfer M., Form A. \& Freiwald A. 2014. Arctic rhodolith beds and their environmental controls (Spitsbergen, Norway). Facies 60, 15-37, doi:10.1007/ s10347-013-0372-2.
Tribollet A., Radtke G. \& Golubic S. 2011. Bioerosion. In J. Reitner \& V. Thiel (eds.): Encyclopedia of geobiology. Pp. 117-134. Dordrecht: Springer.

Vallon L.H., Rindsberg A.K. \& Bromley R.G. 2016. An updated classification of animal behaviour preserved in substrates. Geodinamica Acta 28, 5-20, doi: 10.1080/ 09853111.2015 .1065306$.

Viola R., Nyvall P. \& Pedersén M. 2001. The unique features of starch metabolism in red algae. Proceedings of the Royal Society B: Biological Sciences 268, 1417-1422, doi: 10.1098/ rspb.2001.1644.

Vogel K., Gektidis M., Golubic S., Kiene W.E. \& Radtke G. 2000. Experimental studies on microbial bioerosion at Lee Stocking Island, Bahamas and One Tree Island, Great Barrier Reef, Australia: implications for paleoecological reconstructions. Lethaia 33, 190-204, doi: $10.1080 / 00241160025100053$.

Vogel K. \& Glaub I. 2004. 450 Millionen Jahre Beständigkeit in der Evolution endolithischer Mikroorganismen? (450 millions years of persistance in the evolution of endolithic microorganisms?) Stuttgart: Franz Steiner.

Whitaker D. \& Christman M. 2014. Clustsig: significant cluster analysis. In R package version 1.1. Accessible on the internet at https://CRAN.R-project.org/package=clustsig.

Wiencke C., Clayton M.N., Gómez I., Iken K., Lüder U.H., Amsler C.D., Karsten U., Hanelt D., Bischof K. \& Dunton K. 2006. Life strategy, ecophysiology and ecology of seaweeds in polar waters. Reviews in Environmental Science and Bio/Technology 6, 95-126, doi: 10.1007/ s11157-006-9106-z.

Wisshak M. 2006. High-latitude bioerosion: the Kosterfjord experiment. Berlin: Springer.

Wisshak M. 2008. Two new dwarf Entobia ichnospecies in a diverse aphotic ichnocoenosis (Pleistocene/Rhodes, Greece). In M. Wisshak \& L. Tapanila (eds.): Current developments in bioerosion. Pp. 213-234. Berlin: Springer.

Wisshak M. 2012. Microbioerosion. In D. Knaust \& R. Bromley (eds.): Trace fossils as indicators of sedimentary environments 64. Pp. 213-243. Amsterdam: Elsevier.

Wisshak M. 2017. Taming an ichnotaxonomical Pandora's box: revision of dendritic and rosetted microborings (ichnofamily: Dendrinidae). European Journal of Taxonomy 390 , 1-99, doi: 10.5852/ejt.2017.390.

Wisshak M., Bartholomä A., Beuck L., Büscher J.V., Form A., Freiwald A., Halfar J., Hetzinger S., van Heugten B., Hissmann K., Holler P., Meyer N., Neumann H., Raddatz J., Rüggeberg A., Teichert S. \& Wehrmann A. 2017. Habitat characteristics and carbonate cycling of macrophyte-supported polar carbonate factories (Svalbard). Cruise no. MSM55. June 11-June 29, 2016. Reykjavik (Iceland)—Longyearbyen (Norway). Maria S. Merian-Berichte. Bremen: German Research Foundation, Senate Commission on Oceanography. Doi: $10.2312 / \mathrm{cr} \_m s m 55$.

Wisshak M., Gektidis M., Freiwald A. \& Lundälv T. 2005. Bioerosion along a bathymetric gradient in a cold-temperate setting (Kosterfjord, SW Sweden): an experimental study. Facies 51, 93-117, doi: 10.1007/ s10347-005-0009-1. 
Wisshak M., Meyer N., Radtke G. \& Golubic S. 2018. Saccomorpha guttulata: a new marine fungal microbioerosion trace fossil from cool- to cold-water settings. PalZ 92, 525-533, doi: 10.1007/s12542-018-0407-7.

Wisshak M., Neumann H., Rüggeberg A., Büscher J., Linke P. \& Raddatz J. 2019. Epibenthos dynamics and environmental fluctuations in two contrasting polar carbonate factories (Mosselbukta and Bjørnøy-Banken, Svalbard). Frontiers in Marine Science 6, article no. 667, doi: 10.3389/ fmars.2019.00667.

Wisshak M. \& Porter D. 2006. The new ichnogenus Flagrichnus - a paleoenvironmental indicator for cold-water settings? Ichnos 13, 135-145, doi: 10.1080/10420940600851255.

Wisshak M., Tribollet A., Golubic S., Jakobsen J.C. \& Freiwald A. 2011. Temperate bioerosion: ichnodiversity and biodiversity from intertidal to bathyal depths
(Azores). Geobiology 9, 492-520, doi: 10.1111/j.14724669.2011.00299.x.

Woelkerling W.J. 1990. An introduction. In K.M. Cole \& R.G. Sheath (eds.): Biology of the red algae. Pp. 1-6. Cambridge: Cambridge University Press.

Wulff A., Iken K., Quartino M.L., Al-Handal A., Wiencke C. \& Clayton M.N. 2009. Biodiversity, biogeography and zonation of marine benthic micro- and macroalgae in the Arctic and Antarctic. Botanica marina 52, 491-507, doi: 10.1515/BOT.2009.072.

Zacher K., Rautenberger R., Hanelt D., Wulff A. \& Wiencke C. 2009. The abiotic environment of polar marine benthic algae. Botanica Marina 52, 483-490, doi: 10.1515/ BOT.2009.082

Zenkevitch L. 1963. Biology of the seas of the U.S.S.R. London: George Allen \& Unwin Ltd. 